\title{
Characterization of natural silicate garnets by means of non-destructive testing methods
}

\author{
Irena Balčiūnaitè ${ }^{1 *}$, \\ Ilja Ignatjev ${ }^{1}$, \\ Donatas Kaminskas ${ }^{2}$, \\ Gediminas Niaura ${ }^{1}$, \\ Eugenijus Norkus ${ }^{1}$ \\ ${ }^{1}$ Center for Physical Sciences \\ and Technology (FTMC), \\ 3 Sauletekio Avenue, \\ 01257 Vilnius, Lithuania \\ ${ }^{2}$ Faculty of Chemistry and Geosciences, \\ 24 Naugarduko Street, \\ 03225 Vilnius, Lithuania
}

Two kinds of natural silicate garnets from the known origin countries were investigated: pyralspites - pyrope (Russia), almandine (India), rhodolite (India), spessartine (India), blue colour-change garnet (Sri Lanka), and ugrandites - andradite (Russia), demantoid (Russia), topazolite (Russia), rainbow garnet (Japan), grossular (Kenya-Tanzania), colourless grossular (India), light orange grossular (India), dark green tsavorite (Tanzania), medium green tsavorite (Kenya), light green tsavorite (Kenya), orange hessonite (Sri Lanka), pink hessonite (Sri Lanka), cinnamon hessonite (India) and uvarovite (Russia). The chemical composition of the garnets was performed with a scanning electron microscope. The physical properties such as specific gravity and refractive index were measured for the majority of garnets investigated. The spectroscopic methods - visible light absorption spectrophotometry, Raman spectroscopy and cathodoluminiscence microscopy - were applied for the characterization of the mentioned natural silicate garnets.

Keywords: pyralspite and ugrandite groups, natural silicate garnets, chemical composition, physical properties, visible light absorption spectra, Raman spectroscopy, cathodoluminiscence

\section{INTRODUCTION}

Silicate garnets belong to the nesosilicates group with the general formula $\mathrm{X}_{3} \mathrm{Y}_{2}\left(\mathrm{SiO}_{4}\right)_{3}$. The $\mathrm{X}$ site is usually occupied by divalent cations $\mathrm{Ca}^{2+}, \mathrm{Mg}^{2+}$, $\mathrm{Fe}^{2+}$ and $\mathrm{Mn}^{2+}$ and the $\mathrm{Y}$ site by trivalent cations $\mathrm{Al}^{3+}, \mathrm{Fe}^{3+}$ and $\mathrm{Cr}^{3+}$ in an octahedral/tetrahedral framework with $\left[\mathrm{SiO}_{4}\right]^{4-}$. The major varieties of silicate garnets end-members and their chemical composition are listed in Table 1 .

\footnotetext{
* Corresponding author. Email: irena.balciunaite@ftmc.lt
}

Table 1. Silicate garnets end-members and their theoretical chemical composition

\begin{tabular}{cc}
\hline Garnet & Chemical composition \\
\hline Pyrope & $\mathrm{Mg}_{3} \mathrm{Al}_{2}\left(\mathrm{SiO}_{4}\right)_{3}$ \\
\hline Almandine & $\mathrm{Fe}_{3} \mathrm{Al}_{2}\left(\mathrm{SiO}_{4}\right)_{3}$ \\
\hline Spessartine & $\mathrm{Mn}_{3} \mathrm{Al}_{2}\left(\mathrm{SiO}_{4}\right)_{3}$ \\
\hline Andradite & $\mathrm{Ca}_{3} \mathrm{Fe}_{2}\left(\mathrm{SiO}_{4}\right)_{3}$ \\
\hline Grossular & $\mathrm{Ca}_{3} \mathrm{Al}_{2}\left(\mathrm{SiO}_{4}\right)_{3}$ \\
\hline Uvarovite & $\mathrm{Ca}_{3} \mathrm{Cr}_{2}\left(\mathrm{SiO}_{4}\right)_{3}$ \\
\hline
\end{tabular}

The above-mentioned garnets (Table 1) exist in the nature not only in a form of pure minerals 
with the indicated formulas, but also as mixtures in a form of solid solutions (Fig. 1).

It is worth noting that the above-presented chemical formulas (Table 1) not always reflect the real (true) composition of the garnets under investigation because of possible structural defects in the crystal lattice as well as due to the presence of different impurities.

The real composition of some of the studied garnets was determined earlier by means of electron microprobe analysis [1]. The data were given in a form of oxides (average content) and are listed in Table 2.

The garnets listed in Table 3 were examined by means of different spectroscopy and other non-de-

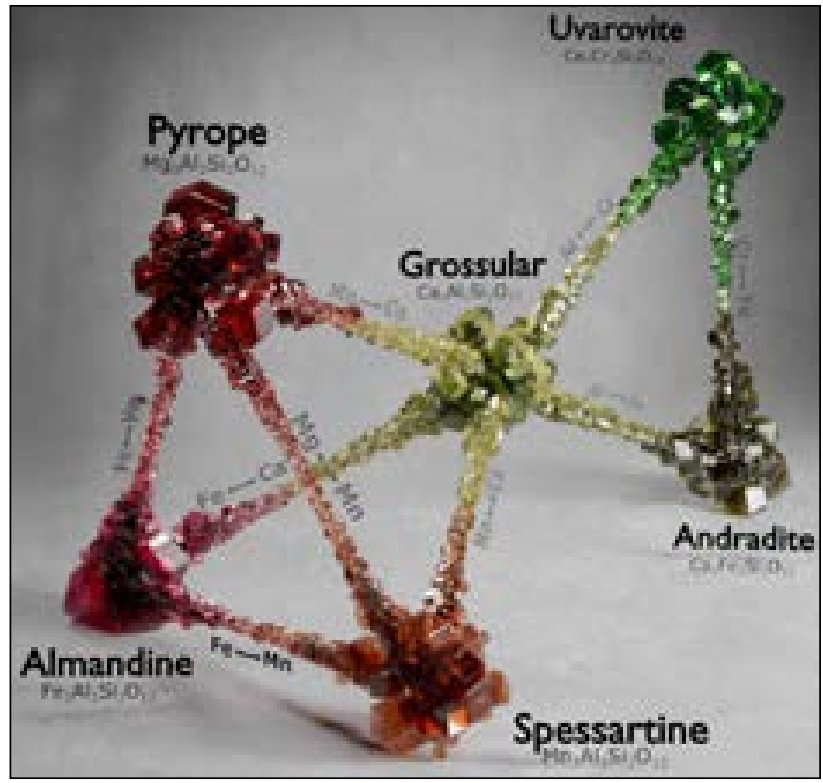

Fig. 1. End-member compositions of the garnet mineral group. (With permission of the author Ms. Lina Jakaitè) structive methods. The results obtained were analysed and compared with the known data (if they are available) of natural garnets originated from different places.

\section{EXPERIMENTAL}

\section{Scanning electron microscopy}

The analysis of the chemical composition of garnet group minerals was performed with a scanning electron microscope Quanta 250/450/650, using an apparatus for coating the samples with metals, Emitech SC7620 Mini Sputter Coater, with a CA7625 attachment for carbon coating.

The distribution of elements in the garnets was analyzed by SEM using a scanning electron microscope (TM4000Plus (Hitachi), magnifications $10 \times-100,000 \times$, accelerating voltage $15 \mathrm{kV}$, image signal - backscattered electrons (BSE), electron gun - pre-centered cartridge tungsten filament.

Each sample was measured from 3 to 5 points. The mean value was calculated.

Specific gravity (or density) values of the garnets were determined hydrostatically, i.e. by weighting of the samples in air and in water by means of the analytical balance. The mean value of at least three measurements was calculated.

Refractive indexes were measured using a standard gemological refractometer Gem LED Refractometer (System Eickhorst) and contact liquid Gem Refraktometer Liquid ${ }^{\mathrm{N}} \mathrm{D}^{25^{\circ} \mathrm{C}}=1.81 \pm 0.005$. It is notable that using this facility the values of the refractive index of the samples investigated can not exceed 1.81. The mean value of at least three measurements was calculated.

Table 2. Silicate garnets and their real chemical composition according to Ref. [1]

\begin{tabular}{|c|c|c|c|c|c|c|c|c|c|}
\hline \multirow{2}{*}{ Garnet } & \multicolumn{9}{|c|}{ Average content of chemical elements (in form of oxides), $\%$} \\
\hline & $\mathrm{SiO}_{2}$ & $\mathrm{CaO}$ & $\mathrm{Al}_{2} \mathrm{O}_{3}$ & MgO & $\mathrm{Fe}_{2} \mathrm{O}_{3}$ & $\mathrm{Cr}_{2} \mathrm{O}_{3}$ & $\mathbf{V}_{2} \mathbf{O}_{3}$ & $\mathrm{MnO}$ & $\mathrm{TiO}_{2}$ \\
\hline Blue colour-changed & 46.24 & 2.43 & 24.01 & 12.53 & 2.33 & 0.37 & 0.44 & 11.81 & \\
\hline Demantoid & 55.44 & 28.51 & 1.18 & & 14.87 & & & & \\
\hline Rainbow & 40.76 & 32.54 & 2.39 & & 24.02 & & & 0.29 & \\
\hline Colourlessgrossular & 54.28 & 15.47 & 28.60 & 1.40 & 0.25 & & & & \\
\hline Light orange grossular & 49.17 & 24.51 & 25.67 & & 0.64 & & & & \\
\hline Dark greentsavorite & 40.80 & 35.14 & 21.89 & 0.61 & & & 0.39 & 0.79 & 0.39 \\
\hline Medium greentsavorite & 41.36 & 34.76 & 21.03 & 0.59 & & 1.00 & 0.35 & 0.56 & 0.36 \\
\hline Pink hessonite & 46.65 & 28.30 & 22.12 & & 2.55 & & & 0.38 & \\
\hline Orange hessonite & 47.21 & 27.79 & 22.33 & & 2.39 & & & 0.29 & \\
\hline
\end{tabular}


Table 3. Silicate garnets investigated, their theoretical chemical composition and origin country

\begin{tabular}{|c|c|c|}
\hline Garnets & Chemical composition & Origin country \\
\hline \multicolumn{3}{|c|}{ Pyralspite group } \\
\hline Pyrope & $\mathrm{Mg}_{3} \mathrm{Al}_{2}\left(\mathrm{SiO}_{4}\right)_{3}$ & Russia \\
\hline Almandine & $\mathrm{Fe}_{3} \mathrm{Al}_{2}\left(\mathrm{SiO}_{4}\right)_{3}$ & India \\
\hline Rhodolite & $(\mathrm{Mg}, \mathrm{Fe})_{3} \mathrm{Al}_{2}\left(\mathrm{SiO}_{4}\right)_{3}$ & India \\
\hline Spessartine & $\mathrm{Mn}_{3} \mathrm{Al}_{2}\left(\mathrm{SiO}_{4}\right)_{3}$ & India \\
\hline \multicolumn{3}{|c|}{ Ugrandite group } \\
\hline Andradite & $\mathrm{Ca}_{3} \mathrm{Fe}_{2}\left(\mathrm{SiO}_{4}\right)_{3}$ & Russia \\
\hline $\begin{array}{c}\text { Demantoid } \\
\text { (variety of andradite) }\end{array}$ & $\mathrm{Ca}_{3} \mathrm{Fe}_{2}\left(\mathrm{SiO}_{4}\right)_{3}$ & Russia \\
\hline $\begin{array}{c}\text { Topazolite } \\
\text { (variety of andradite) }\end{array}$ & $\mathrm{Ca}_{3} \mathrm{Fe}_{2}\left(\mathrm{SiO}_{4}\right)_{3}$ & Russia \\
\hline $\begin{array}{c}\text { Rainbow garnet } \\
\text { (variety of andradite) }\end{array}$ & $\mathrm{Ca}_{3} \mathrm{Fe}_{2}\left(\mathrm{SiO}_{4}\right)_{3}$ & Japan \\
\hline Grossular & $\mathrm{Ca}_{3} \mathrm{Al}_{2}\left(\mathrm{SiO}_{4}\right)_{3}$ & Kenya-Tanzania \\
\hline $\begin{array}{l}\text { Dark green tsavorite } \\
\text { (variety of grossular) }\end{array}$ & $\mathrm{Ca}_{3} \mathrm{Al}_{2}\left(\mathrm{SiO}_{4}\right)_{3}$ & Tanzania \\
\hline $\begin{array}{c}\text { Medium green tsavorite } \\
\text { (variety of grossular) }\end{array}$ & $\mathrm{Ca}_{3} \mathrm{Al}_{2}\left(\mathrm{SiO}_{4}\right)_{3}$ & Kenya \\
\hline $\begin{array}{l}\text { Light green tsavorite } \\
\text { (variety of grossular) }\end{array}$ & $\mathrm{Ca}_{3} \mathrm{Al}_{2}\left(\mathrm{SiO}_{4}\right)_{3}$ & Kenya \\
\hline $\begin{array}{c}\text { Orange hessonite } \\
\text { (variety of grossular) }\end{array}$ & $\mathrm{Ca}_{3} \mathrm{Al}_{2}\left(\mathrm{SiO}_{4}\right)_{3}$ & Sri Lanka \\
\hline Pink hessonite (variety of grossular) & $\mathrm{Ca}_{3} \mathrm{Al}_{2}\left(\mathrm{SiO}_{4}\right)_{3}$ & Sri Lanka \\
\hline Cinnamon hessonite (variety of grossular) & $\mathrm{Ca}_{3} \mathrm{Al}_{2}\left(\mathrm{SiO}_{4}\right)_{3}$ & Sri Lanka \\
\hline Uvarovite & $\mathrm{Ca}_{3} \mathrm{Cr}_{2}\left(\mathrm{SiO}_{4}\right)_{3}$ & Russia \\
\hline
\end{tabular}

$2 \mathrm{~mm}$ thin slices of the garnets under investigation were used in all spectral experiments. The experiments were carried out at room temperature.

Cathodoluminescence investigations were carried out using a Nikon Eclipse E200 polarizing microscope (magnification $40 \times$ ) and cathodoluminescope model CITL Mk5-2 ( $\sim 15 \mathrm{kV}$ voltage and 350-400 mA current).

Light absorption spectra were recorded using a Perkin Elmer Lambda 35 UV/VIS spectrometer in the wavelength interval $400-800 \mathrm{~nm}$.

With the aim to compare the results obtained in the nanometers scale with that presented in the wavenumber $\left(\mathrm{cm}^{-1}\right)$ scale the recalculation was made: wavelength (in $\mathrm{nm})=10000000 /$ wavenumber $\left(\mathrm{cm}^{-1}\right)$, e.g. $400 \mathrm{~nm}=25000 \mathrm{~cm}^{-1}$ or $750 \mathrm{~nm}=13333 \mathrm{~cm}^{-1}$.

\section{Raman spectroscopy}

Raman spectra were recorded with an Echelle type spectrometer RamanFlex 400 (PerkinElmer, Inc.) equipped with a thermoelectrically cooled $\left(-50^{\circ} \mathrm{C}\right)$ CCD detector and a fiber optic cable for excitation and collection of the spectra. The diode laser with a $785 \mathrm{~nm}$ beam was used as an excitation source. The laser power was $30 \mathrm{~mW}$. The laser beam was focused to a $200 \mu \mathrm{m}$ diameter spot on the surface of the investigated samples. All spectra were divided by the total accumulation time. The polystyrene standard (ASTM E1840) spectrum was used to calibrate Raman frequencies. The Grams/AI 8 (Thermo Scientific Inc., JAV) software was used for the recorded spectra analysis. The experiments were carried out at room temperature.

\section{RESULTS AND DISCUSSION}

\section{Chemical composition of garnets}

After publication of the data on the chemical composition of nine different silicate garnets (Table 1) [1], we have possessed new samples of silicate garnets and have determined the mean values of their 
chemical composition (Table 4). The data obtained (Table 4) together with the data of Table 2 were used for further interpretation of the below discussed topics.

Pyrope (Fig. 2) is the only member of the garnet family to always display red colouration in natural samples, and it is from this characteristic that it gets its name: from the Greek for fire and eye. Sometimes it is with an alexandrite effect of green, lilac and blue in daylight and purple and raspberry in artificial light. This variety was first called that by A. Werner in 1803. These garnets are sometimes called Bohemian garnets, after the old German name of western Czech Republic. Pyrope is usually red, pink, orangered, raspberry, cherry and reddish purple. The luster is glassy. The refractive index is $1.705-1.785$, density $3.65-3.87 \mathrm{~g} / \mathrm{cm}^{3}$ and hardness $7-7.5$ [2]. Pure pyrope has not yet been found, it is found in nature as a mixture with almandine and grossular. After the determination of chemical elements in pyrope, it was found out that the content of magnesium oxide

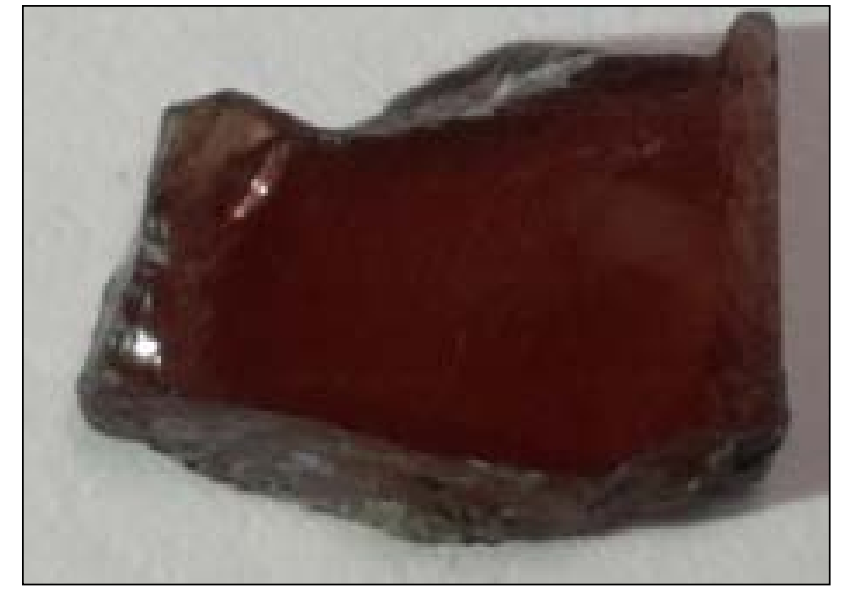

Fig. 2. Pyrope (Russia). Photo by I. Balčiūnaitè

varies from 13.67 to $14.49 \%$, that of aluminium(III) oxide from 22.30 to $23.00 \%$ and that of iron(III) oxide from 20.29 to $22.98 \%$, which are characteristic of pyrope and its varieties. In this mineral, silicon(IV) oxide varies from 38.26 to $39.59 \%$ and that of calcium oxide from 2.63 to $2.79 \%$.

Table 4. Silicate garnets investigated and their real chemical composition

\begin{tabular}{|c|c|c|c|c|c|c|c|c|c|}
\hline \multirow{2}{*}{ Garnet } & \multicolumn{9}{|c|}{ Average content of chemical elements (in form of oxides), $\%$} \\
\hline & $\mathrm{SiO}_{2}$ & $\mathrm{CaO}$ & $\mathrm{Al}_{2} \mathrm{O}_{3}$ & Mg0 & $\mathrm{Fe}_{2} \mathrm{O}_{3}$ & $\mathrm{Cr}_{2} \mathrm{O}_{3}$ & $\mathrm{~V}_{2} \mathrm{O}_{3}$ & MnO & $\mathrm{TiO}_{2}$ \\
\hline \multicolumn{10}{|c|}{ Pyralspite group } \\
\hline Pyrope & 38.95 & 2.70 & 22.74 & 14.08 & 21.41 & & & 0.12 & \\
\hline Almandine & 34.57 & 0.48 & 25.05 & 4.47 & 35.18 & & & 0.25 & \\
\hline Rhodolite & 32.63 & 2.02 & 36.52 & 9.15 & 19.05 & & & 0.64 & \\
\hline Spessartine & 37.51 & 1.64 & 22.26 & 2.33 & 0.70 & & & 35.55 & \\
\hline $\begin{array}{l}\text { Blue colour-change (mixed pyrope and } \\
\text { spessartine) garnet }\end{array}$ & 46.08 & 2.43 & 24.01 & 12.53 & 2.33 & 0.37 & 0.44 & 11.85 & \\
\hline \multicolumn{10}{|c|}{ Ugrandite group } \\
\hline Andradite & 47.40 & 28.55 & 16.04 & 1.41 & 6.61 & & & & \\
\hline Demantoid (variety of andradite) & 55.44 & 28.51 & 1.18 & & 14.87 & & & & \\
\hline Topazolite (variety of andradite) & 38.55 & 29.54 & 1.74 & 1.90 & 28.39 & 0.04 & 0.09 & & 0.05 \\
\hline Rainbow garnet (variety of andradite) & 40.76 & 32.54 & 2.39 & & 24.02 & & & 0.29 & \\
\hline Grossular & 39.47 & 34.78 & 23.06 & 0.44 & 0.47 & 0.22 & 0.64 & 0.92 & \\
\hline Colourless grossular & 54.28 & 15.47 & 28.60 & 1.40 & 0.25 & & & & \\
\hline Dark green tsavorite (variety of grossular) & 40.80 & 35.14 & 21.89 & 0.61 & & & 0.39 & 0.79 & 0.39 \\
\hline Medium greentsavorite (variety of grossular) & 41.36 & 34.76 & 21.03 & 0.59 & & 1.00 & 0.35 & 0.56 & 0.36 \\
\hline Light green tsavorite (variety of grossular) & 40.17 & 34.34 & 23.41 & 0.50 & & 0.09 & 0.13 & 0.91 & 0.44 \\
\hline Orange hessonite (variety of grossular) & 47.21 & 27.79 & 22.33 & & 2.39 & & & 0.29 & \\
\hline Pink hessonite (variety of grossular) & 46.65 & 28.30 & 22.12 & & 2.55 & & & 0.38 & \\
\hline Cinnamon hessonite (variety of grossular) & 49.17 & 24.51 & 25.67 & & 0.64 & & & & \\
\hline Uvarovite & 22.80 & 3.52 & 44.07 & 16.16 & 7.77 & 5.68 & & & \\
\hline
\end{tabular}


The name almandine (Fig. 3) comes from the Alabanda area of Turkey, where the 'alabanda carbuncles' were mined, described back in Pliny's (77 years B. C.). The name was granted by Georg Agrikola in 1546. It is purple-red, red, red with a brown tinge and dark red (almost black). Gloss is glass, refractive index $1.78-1.81$, density $3.95-4.20 \mathrm{~g} / \mathrm{cm}^{3}$ and hardness 7.5 [2]. After the determination of chemical elements in almandine it was found out that the content of aluminium(III) oxide varies from 25.90 to $29.92 \%$ and that of iron(III) oxide from 10.45 to $18.82 \%$, which are characteristic of almandine and its varieties. In this mineral, magnesium oxide varies from 6.13 to $7.95 \%$, silicon(IV) oxide from 48.85 to $53.71 \%$ and manganese(II) oxide and calcium oxide levels were found to be up to $0.5 \%$.

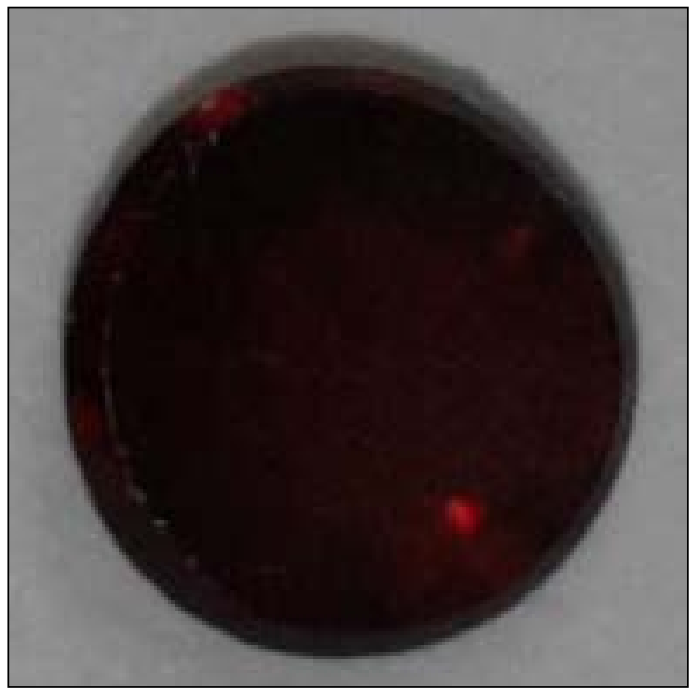

Fig. 3. Almandine (India). Photo by I. Balčiūnaitè

The name rhodolite (Fig. 4) comes from the Greek rose-like. The colour is reddish pink. The hardness according to the Mohs scale is 7-7.5, the density $3.84(+/-0.10)$ and the refractive index $1.760(+0.010-0.020)$. The absorption spectra typically have absorption maxima at 504, 520 and $573 \mathrm{~nm}$, and may also have a weak line at 423,460, 610 and $680-690 \mathrm{~nm}$ [3]. Rhodolite is a mixture of pyrope and almandine. After the determination of chemical elements in rhodolite, it was found out that the content of magnesium oxide varies from 10.49 to $16.87 \%$ and the aluminium(III) oxide content varies from 30.86 to $35.48 \%$, which are characteristic of rhodolite and its varieties. In this mineral, iron(III) oxide varies from 1.11 to $2.06 \%$, that of silicon(IV)

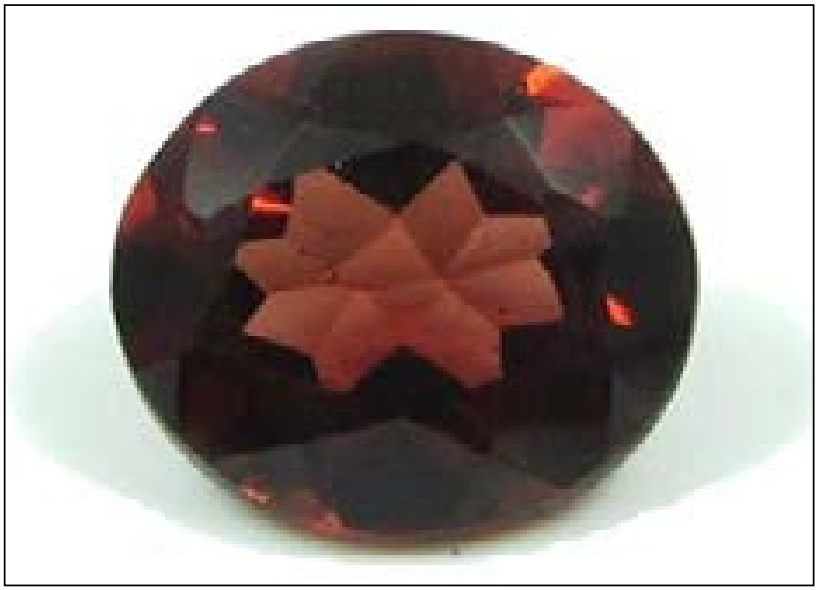

Fig. 4. Rhodolite (India). Photo by I. Balčiūnaitè

oxide from 50.61 to $54.93 \%$ and manganese(II) oxide and calcium oxide levels were found to be up to $0.5 \%$.

Spessartine (Fig. 5) was named after the Spessart area in Germany in 1832. The name was given by F. Biodan. Its beauty is defined primarily by its colour: orange, red-orange and yellow-brown. Gloss is glassy, the refractive index 1.79-1.82, the density $4.12-4.20 \mathrm{~g} / \mathrm{cm}^{3}$ and the hardness $7-7.5$ [2]. After the determination of chemical elements in spesartine, it was found out that the content of manganese(II) oxide varies from 34.70 to $36.59 \%$ and that of aluminium(III) oxide from 21.43 to $23.13 \%$, which are characteristic of spessartine and its varieties. In this mineral, the iron(III) oxide content varies from 0.00 to $0.95 \%$, that of silicon(IV) oxide from 36.65 to $38.33 \%$, that of magnesium oxide from 0.00 to $4.80 \%$ and the content of calcium oxide varies from 1.5 to $1.80 \%$.

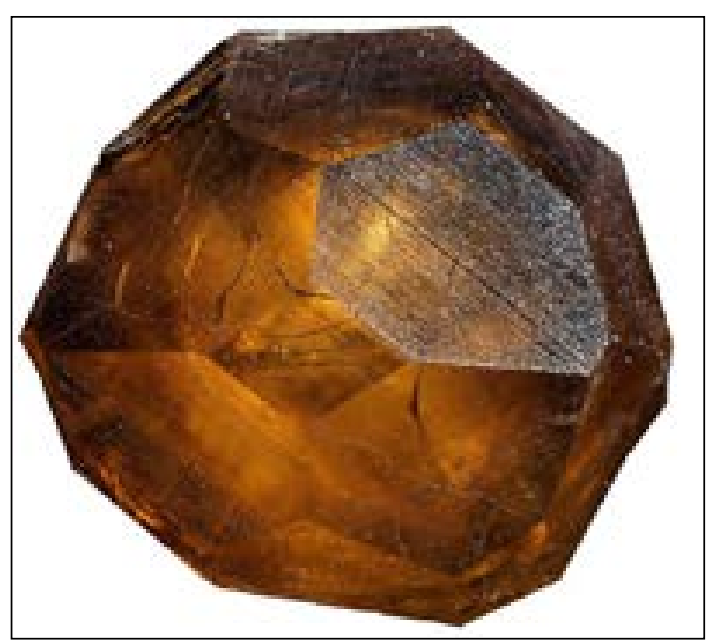

Fig. 5. Spesartine (India). Photo by I. Balčiūnaitė 
The blue colour-change garnet (Fig. 6) is the only one known example of blue garnets. This garnet is not of blue colour only, thus, it would not be entirely correct to refer to it as the blue garnet. The most interesting thing is that this garnet can change its colour in the same manner as alexandrite, therefore, the most correct name for this garnet would be the blue colour-change garnet [t. The test of chemical elements showed that this garnet is a mixture of pyrope and spessartine. Magnesium oxide is characteristic of pyrope, whereas manganese oxide is characteristic of spessartine, and these two, in addition to aluminium(III) and silicon(IV) oxides, form the core of the chemical composition of these elements; this is confirmed by the tests of other authors [5]. In the garnet tested in this work, the content of magnesium oxide varies from 11.18 to $13.43 \%$, that of magnesium oxide from 8.63 to $17.37 \%$, that of aluminium(III) oxide from 22.03 to $25.29 \%$ and the content of silicon(IV) oxide from 42.24 to $48.75 \%$. In addition to these elements, the designated content of calcium oxide varies from 2.13 to $2.88 \%$, that of iron(III) oxide from 1.78 to $3.32 \%$, and the content of colour determining chemical elements, i.e. vanadium(III) oxide, varies from 0.38 to $0.50 \%$ and that of chromium(III) oxide concentration about $0.37 \%$.

Andradite (Fig. 7) was named by James Dwight Dana in 1868 in honour of José Bonifácio de Andrada de Silva, Brazilian mineralogist, who first described and named what Dana (1868) defined as a subvariety of andradite. d'Andrada had earlier, in 1800, discovered a yellowish-grey mineral from a mine near Drammen, Buskerud, Norway [6].

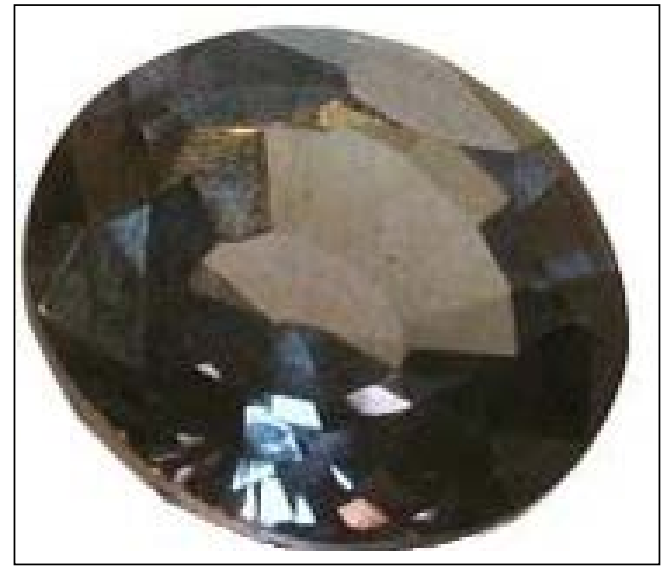

Fig. 6. Blue colour-change garnet (Sri Lanka). Photo by photographer Irzhi Korn
After the determination of chemical elements in andradite, we found out that the content of calcium oxide varies from 27.64 to $29.45 \%$ and that of aluminium(III) oxide from 15.97 to $16.11 \%$, which are characteristic of andradite and its varieties. In this mineral, the content of iron(III) oxide varies from 6.53 to $6.69 \%$, that of magnesium oxide content varies from 1.05 to $1.77 \%$ and that of silicon(IV) oxide from 54.28 to $56.45 \%$.

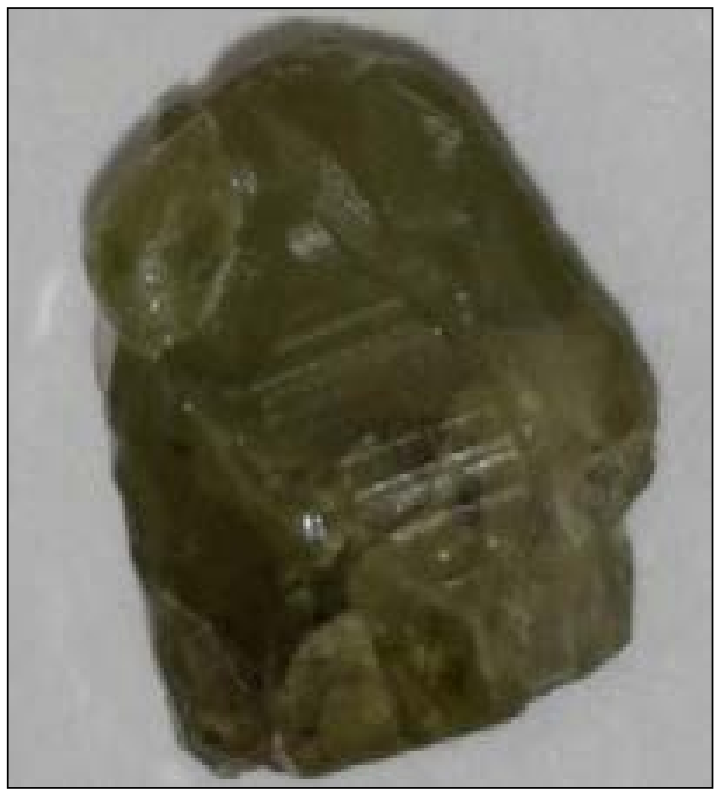

Fig. 7. Andrdite (Russia). Photo by I. Balčiūnaitè

Demantoid (Fig. 8a, b, c) is a variety of andradite. It is characterized by diamond lustre, which gave it the name in the 19th century. The colour varies from cold, very pale green to mid or strong green, not, as a rule, a very livery colour and similar to certain shades of green in tourmaline, zircon, or olivine [5]. After the determination of chemical elements in demantoid, it was found out that the content of calcium oxide varies from 28.23 to $28.75 \%$ and that of iron(III) oxide from 13.93 to $15.99 \%$, which are characteristic of andradite and its varieties. In this mineral, the aluminium(III) oxide content varies from 0.99 to $1.38 \%$ and that of silicon(IV) oxide from 54.28 to $56.45 \%$. The green colour of this variety is determined by chromium [申].

Topazolite (Fig. 8d, e, f) is a variety of andradite. It was named in allusion to the resemblance with topaz (in colour and transparency) [8]. In the garnet tested, the content of calcium oxide 
varies from 27.96 to $30.68 \%$ and that of iron(III) oxide from 26.15 to $29.84 \%$, which are characteristic of andradite and its varieties. In this mineral, the aluminium(III) oxide content varies from 1.55 to $1.99 \%$, that of silicon(IV) oxide from 36.44 to $40.85 \%$, magnesium oxide varies from 0.00 to $2.95 \%$, titanium(IV) oxide from 0.02 to $0.10 \%$ and colour determining chemical elements, i.e. vanadium(III) oxide about $0.21 \%$ and the content of chromium(III) oxide varies from 0.01 to $0.05 \%$.

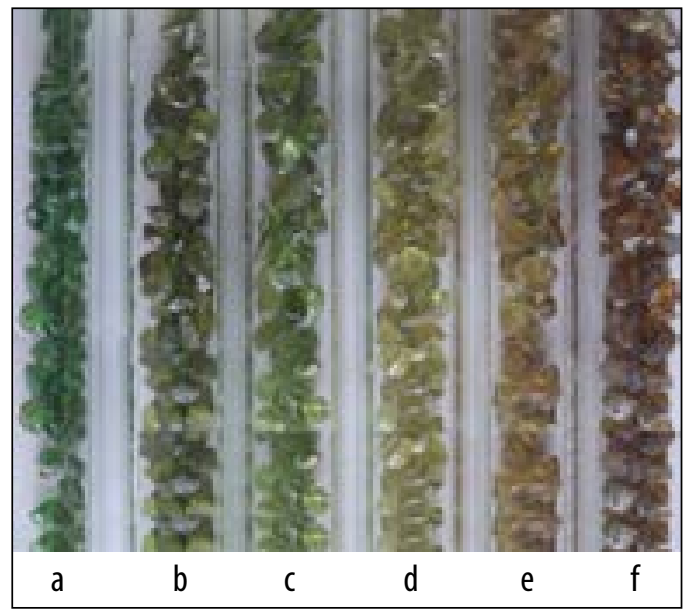

Fig. 8. (a, b, c) Demantoid (Russia). (d, e, f) Topazolite (Russia). Photo by I. Baliūnaitè

Rainbow garnet (Fig. 9) is called in this way because its surface glows like a rainbow. After the chemical analysis, it was indicated that the content of calcium oxide varies from 32.19 to $32.95 \%$, iron(III) oxide from 23.49 to $24.91 \%$, silicon(IV) oxide from 39.51 to $41.71 \%$, aluminium(III) oxide from 1.71 to $3.64 \%$ and manganese(II) oxide from 0.24 to $0.32 \%$. Based on the results of the tests, it was found out that the chemical composition of the rainbow garnet is as that of andradite variety. By comparing the chemical composition of this rare variety with another tested variety of andradite, i.e. demantoid and topazolite, it was found out that the content of manganese(II) oxide in the rainbow garnet varies from 0.24 to $0.32 \%$, whereas in demantoid and topazolite there is none. What is more, the content of iron(III) oxide (from 23.49 to $24.91 \%$ ) in the rainbow garnet is higher than in demantoid (from 13.93 to $15.99 \%$ ) but lower than in topazolite (from 26.15 to $29.84 \%$ ). These differences in the chemical composition

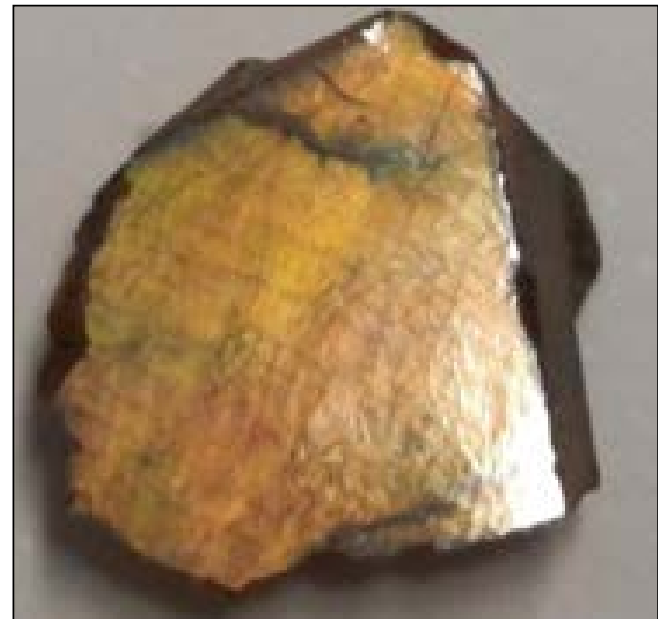

Fig. 9. Rainbow garnet (Japan). Photo by I. Balčiūnaitè

determine the difference in colour, and the multicolourfulness of the rainbow garnet should depend on the surface reflectivity, i. e. irisation.

Grossular (Fig. 10) has most varieties among the garnet group minerals. Its name is derived from the Latin word grossularia (Eng. gooseberry). Since the 1960s, it has been found in gem quality, mainly green [9]. However, this mineral can also be of other colours depending on impurities, even colourless. In the garnet tested, the content of calcium oxide varies from 32.15 to $36.05 \%$, aluminium(III) oxide from 22.76 to $24.48 \%$ and silicon(IV) oxide from 39.20 to $39.91 \%$. In addition to these elements, the designated content of iron(III) oxide varies from 0.00 to $1.45 \%$, magnesium oxide from 0.00 to 0.49 , manganese(II) oxide from 0.60 to $1.56 \%$ and colour determining chemical elements, i.e. vanadium(III) oxide content varies from 0.00 to $1.23 \%$ and that of chromium oxide from 0.00 to $0.45 \%$.

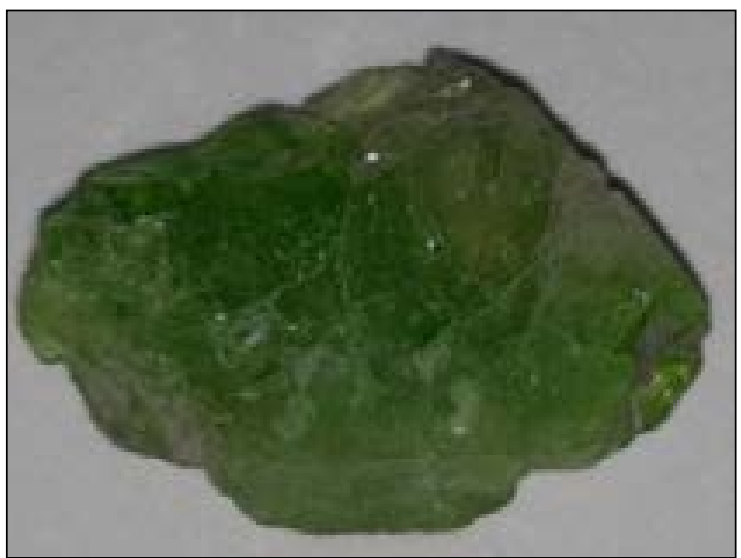

Fig. 10. Grossular (Kenya). Photo by I. Balčiūnaitè 
In the tested colourless grossular (Fig. 11), the content of magnesium oxide found varies from 1.55 to $1.24 \%$, aluminium(III) oxide from 27.14 to $30.14 \%$, silicon(IV) oxide from 52.95 to $55.75 \%$, calcium oxide from 12.56 to $18.42 \%$ and iron(III) oxide about $0.25 \%$. Based on the results of the tests, it was found out that there were no colour-determining chromophores in the mineral, except for $0.25 \%$ of iron(III) oxide, which may not affect the colour at all.

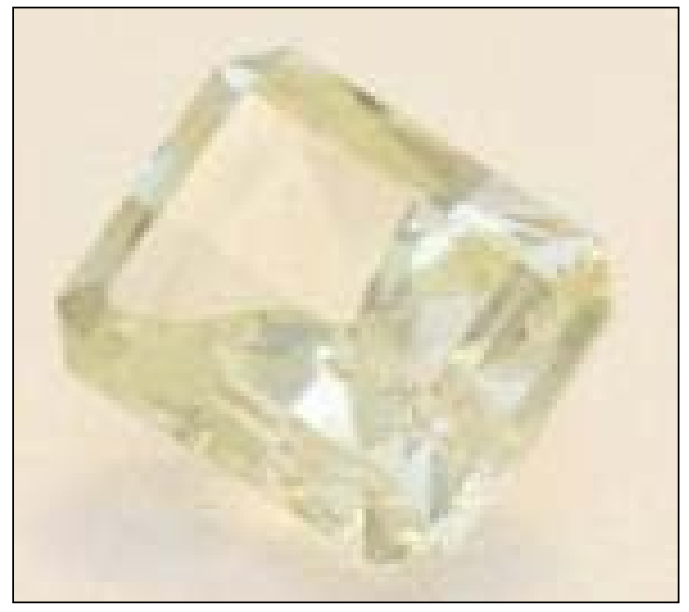

Fig. 11. Colourless grossular (India). Photo by Irzhi Korn

Tsavorite (Fig. 12) is a variety of grossular, characterized by green colour. Its name was proposed by Tiffany and Co. President, Sir Henry Platt, after the Tsavo East National Park, Kenya, which lies near the place where tsavorite was originally found. In the dark green tsavorite (Fig. 13a), the content of magnesium oxide was found to vary from 0.58 to $0.64 \%$, aluminium(III) oxide from 21.89 to $21.92 \%$, silicon(IV) oxide from 40.79 to $40.89 \%$, calcium oxide from 35.06 to $35.30 \%$, vanadium(III) oxide from 0.32 to $0.47 \%$, manganese(II) oxide from 0.76 to $0.81 \%$ and the content of titanium(IV) found is about $0.39 \%$. In the medium green tsavorite (Fig. 13b), the content of magnesium oxide was found to vary from 0.40 to $0.73 \%$, aluminium(III) oxide from 20.12 to $21.52 \%$, silicon(IV) oxide from 39.62 to $43.90 \%$, calcium oxide from 31.91 to $37.59 \%$, vanadium(III) oxide about $0.35 \%$, chromium(III) oxide from 0.98 to $1.04 \%$, manganese(II) oxide from 0.42 to $0.72 \%$ and titanium(IV) oxide from 0.35 to $0.37 \%$. In the light green tsavorite (Fig. $13 \mathrm{c}$ ), the content of magnesium oxide was found to vary from 0.43 to $0.55 \%$, aluminium(III) oxide from 23.07 to $24.30 \%$, silicon(IV) oxide from 39.95 to $41.13 \%$, calcium ox-

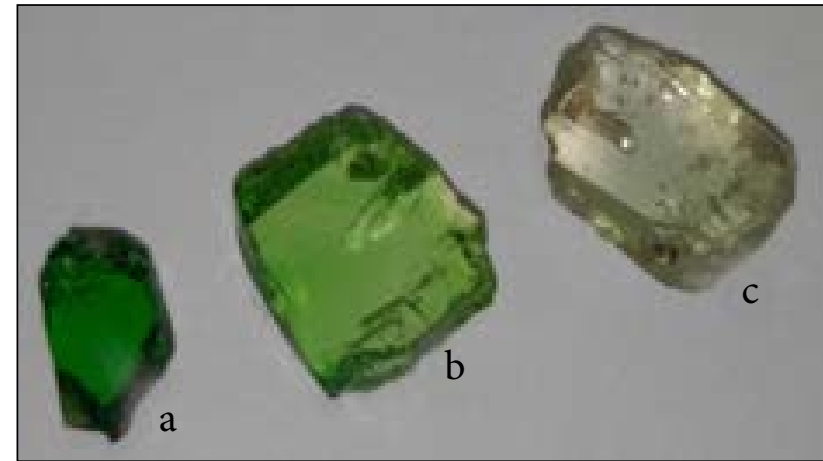

Fig. 12. Tsavorite (Kenya and Tanzania): (a) dark green, (b) medium green and $(c)$ light green. Photo by I. Balčiūnaitè

ide from 34.27 to $35.10 \%$, vanadium(III) oxide from 0.00 to $0.26 \%$, chromium(III) oxide from 0.00 to $0.018 \%$, manganese(II) oxide from 0.00 to $1.06 \%$ and titanium(IV) oxide from 0.00 to $0.53 \%$. The highest levels of vanadium, manganese and titanium(IV) oxides were found in dark green tsavorite, the lower levels in medium green tsavorite and the lowest levels in light green tsavorite. Comparing the analytical data between tsavorites, it was found that dark green tsavorite contains mainly magnesium(II), calcium(II), vanadium(III), manganese(II) and titanium(IV) oxides. Medium green tsavorite has more chromium than other tsavorites studied.

In light orange grossular (Fig. 13), there are predominantly aluminium(III) and calcium oxides. Having performed the tests, it was found out that the aluminium(III) oxide content varies from 23.91 to $27.84 \%$ and the calcium oxide content varies from 18.13 to $28.59 \%$. At different points of the sample testing, it was found out that if the aluminium(III) oxide content increases, the content of calcium and iron(III) oxides become lower. The silicon(IV) oxide content was found to vary from 46.62 to $54.09 \%$. Based on the results of the tests, it is presumed that the content of iron(III) oxide, which determines the colour of this variety, varies from 0.38 to $0.88 \%$.

Hessonite (Fig. 14) is a variety of grossular, which can vary from yellow to brown colour; sometimes this variety is referred to as essonite. Those are honey-yellow and yellow-brown garnets, tending to a reddish orange colour similar to that of spessartine. Its name comes from the Greek word esson, which means inferior. Minerals of this colour are regarded as less valuable. Brown colour hessonite is of the lowest value. Hessonites have a good luster 


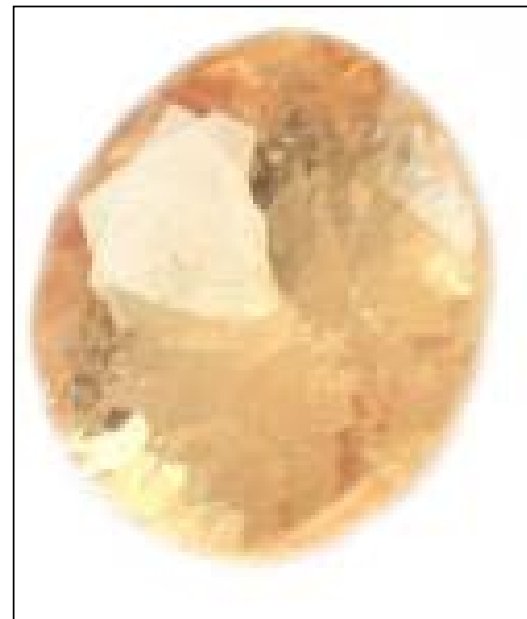

Fig. 13. Light orange grossular (India). Photo by photographer Irzhi Korn

and seemingly a good transparency, but when viewed with a lens, they seem to be undulated, in places of inclusions the view becomes contorted and they become non-transparent. Due to its colour hessonite is also called cinnamon garnet. In the tested orange hessonite (Fig. 14a), there are predominantly calcium and aluminium oxides. The amount of aluminium(III) found during the analysis varies from 22.23 to $23.68 \%$, calcium oxide from 27.73-35.36, silicon(IV) oxide from 41.33-47.25\%, iron(III) oxide $2.36-2.41 \%$ and manganes(II) about $0.30 \%$. In the tested pink hessonite (Fig. 14b), there are predominantly calcium and aluminium(III) oxides. The amount of aluminium(III) found during the analysis varies from 21.89 to $22.29 \%$, calcium oxide from 27.52-29.53, silicon(IV) oxide from $45.34-47.51 \%$, and manganes(II) oxide from 0.35 to $0.41 \%$ and iron (III) oxide $2.35-2.84 \%$.

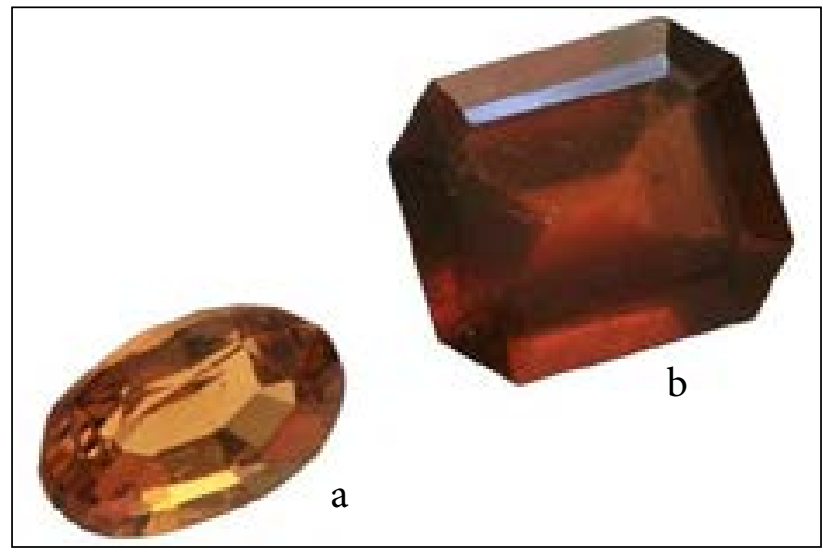

Fig. 14. Hessonite: (a) orange hessonite (Sri Lanka) and (b) pink hessonite (India). Photo by photographer Irzhi Korn
In the tested cinnamon hessonite (Fig. 15), there are predominantly silicon(IV), calcium and aluminium(III) oxides. The amount of aluminium(III) found during the analysis varies from 20.20 to $36.37 \%$, calcium oxide from 22.26 26.93, silicon(IV) oxide from $33.52-52.46 \%$ and iron(III) oxide about $0.64 \%$.

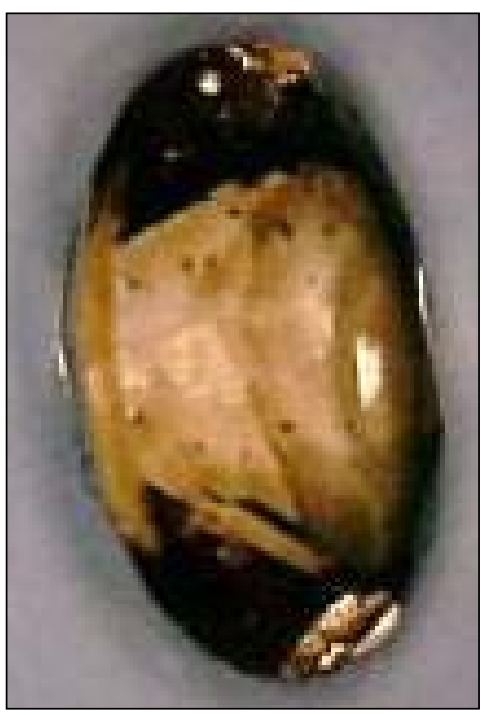

Fig. 15. Cinnamon hessonite. Photo by A. Balčiūnaitè

Uvarovite (Fig. 16) usually forms small crystals and groups of joint crystals. In 1832, H. Hess named uvarovite in honor of Count S. Uvarov (1786-1855), Russian statesman and scholar,

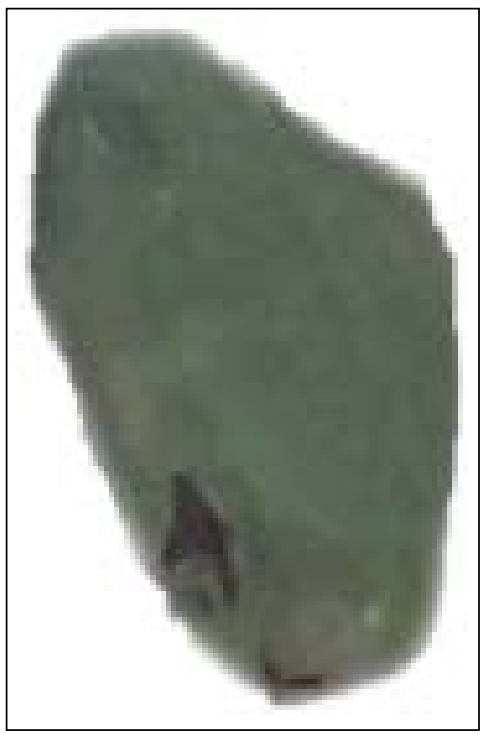

Fig. 16. Uvarovite (Russia). Photo by I. Balčiūnaitè 
President of the Russian Academy of Science. Its density was found to be equal to 3.7 [10]. In the uvarovite tested, the content of calcium oxide varies from 2.71 to $4.34 \%$, chromium(III) oxide from 4.77 to $6.58 \%$, aluminium(III) oxide from 43.41 to $44.73 \%$, silicon(IV) oxide from 22.67 to $22.93 \%$ and the content of magnesium oxide varies from 14.53 to $17.80 \%$.

\section{Specific gravity (or density) of garnets}

Different types of gemstones vary in density, therefore the measurements of the specific gravity can be performed by one of the methods for their characterization. In gemology, the density or specific gravity of a gemstone is computed as the ratio of the density of the material to the density of water. The density is expressed as a number which indicates how much heavier the gemstone is compared to an equal volume of water. The specific gravity $(\rho)$ can by expressed as ratio of the weight of the substance to the volume unit. Since till now in many textbooks the dimension of the specific gravity is expressed in $\mathrm{g} / \mathrm{cm}^{3}$, with the aim to make comparison of the data, we have determined the specific gravity of garnets investigated in the same dimension.

It can be noted that the specific gravity of silicate garnets ranges from 3.50 to $4.20 \mathrm{~g} / \mathrm{cm}^{3}$ [1]. Our data obtained fit into the mentioned range (Table 5).

According to Table 5, the determined specific gravity of the investigated grossulars was in the range from 3.54 to $3.63 \mathrm{~g} / \mathrm{cm}^{3}$ and are in a good agreement with the literature data. The specific gravity of the dark green, medium green and light green tsavorites are $3.62,3.66$ and $3.61 \mathrm{~g} / \mathrm{cm}^{3}$, respectively. Probably, different amounts of $\mathrm{Mn}(\mathrm{II})$, $\mathrm{Cr}$ (III) and V(III) (Table 2) determine the difference in the values of specific gravity. The specific gravity of pink hessonite $\left(3.74 \mathrm{~g} / \mathrm{cm}^{3}\right)$ is higher than that of orange hessonite $\left(3.71 \mathrm{~g} / \mathrm{cm}^{3}\right)$ and can be accounted for the higher content of $\mathrm{Fe}^{3+}$ and $\mathrm{Mn}(\mathrm{II})$ in pink hessonite (Table 2). The highest value of the specific gravity was measured for uvarovite $\left(3.77 \mathrm{~g} / \mathrm{cm}^{3}\right)$, whereas the lowest value was obtained for hydrogrossular $-3.52 \mathrm{~g} / \mathrm{cm}^{3}$.

\section{Refractive indexes of garnets}

The refractive index is one of the most important signatures of a gemstone. Measuring the refractive index is one of the first steps in identifying the gemstone, though some gems have similar refractive indices and additional tests are required for a definitive identification. The refractive index is the difference between the speed of light in a vacuum and the speed of light in the gemstone. As light passes through the gemstone, it slows down because the gemstone is denser than air. This causes the path of light to change. Refraction is the bending of light as it passes in or out of a gem. The angle of refraction in the stone determines its refractive index. Gemstones with a high refractive index are more brilliant than those with a low refractive one.

Table 5. Specific gravity of the investigated garnets

\begin{tabular}{c|c|c}
\hline Garnet & $\begin{array}{c}\text { Determined specific } \\
\text { gravity }(\mathbf{p}), \mathbf{g} / \mathbf{c m}^{3}\end{array}$ & Data from other sources, $\mathbf{g} / \mathbf{c m}^{\mathbf{3}}$ \\
\hline $\begin{array}{c}\text { Demantoid } \\
\text { (variety of andradite) }\end{array}$ & 3.67 & $3.70-4.10[11] ; 3.82-3.85[12] ; 3.81-3.87[13]$ \\
\hline Grossular & 3.63 & $3.56-3.73[11] ; 3.42-3.72[14] ; 3.6[10]$ \\
\hline Hydrogrossular & 3.52 & $3.45-3.56[14]$ \\
\hline Green grossular & 3.62 & $3.62[12]$ \\
\hline Light orange grossular & 3.54 & $3.56-3.73[11]$ \\
\hline Dark green tsavorite & 3.62 & $3.56-3.73[11] ; 3.50-3.75[12]$ \\
\hline Medium green tsavorite & 3.66 & $3.56-3.73[11] ; 3.50-3.75[12]$ \\
\hline Light green tsavorite & 3.61 & $3.41-3.52[11] ; 3.4-3.8[12,14] ; 3.7[10]$ \\
\hline Orange hessonite & 3.71 & \\
\hline Pink hessonite & 3.74 & \\
\hline Uvarovite & 3.77 & \\
\hline
\end{tabular}


Table 6. Refractive indexes of the investigated garnets

\begin{tabular}{ccc}
\hline Garnet & Refractive index & Data from other sources \\
\hline Rhodolite & 1.775 & $1.742-1.785[15]$ \\
\hline Grossular & 1.734 & $1.734-1.759[15] ; 1.730-1.760[16]$ \\
\hline Dark green tsavorite & 1.740 & $1.734-1.759[15]$ \\
\hline Medium green tsavorite & 1.740 & $1.731-1.732[12] ;[1.74-1.76[13]$ \\
\hline Light green tsavorite & 1.740 & $1.74-1.76[13] ; 1.730-1.760[16]$ \\
\hline Orange hessonite & 1.738 & $1.730-1.760[16]$ \\
\hline Pink hessonite & 1.745 &
\end{tabular}

It can be noted that the refractive indexes of silicate garnets range from 1.73 to 1.89 [15]. Our data obtained fit into the mentioned range (Table 6).

When comparing the results obtained (Table 6) it is obvious that rhodolite has the highest value of the refractive index, whereas the lowest value was determined for grossular. Other garnets have comparable values of the refractive index. It is notable that due to the limitation of the experimental equipment (see the Experimental part) we have had investigated only samples with the refraction index lower than 1.81. For instance, uvarovite and demantoid have much higher refractive indexes, e.g. 1.865 and ca. 1.91 , respectively [5].

\section{Cathodoluminescence investigations}

Cathodoluminescence (CL) is an optical and electromagnetic phenomenon in which electrons impacting on a luminescent material cause the emission of photons which may have wavelengths in the visible spectrum. The cathodoluminescence emission from a rock can provide insights into crystal growth, zonation, cementation, chemical replacement, deformation, provenance, trace elements and defect structures. CL presents a valuable technique for fundamental sedimentary, metamorphic and igneous rock studies but also for more applied studies on ores or precious gems [17-22].

When investigating cathodoluminiscence of silicate garnets in the presented work, it was found that pyrope and rhodolite exhibit an intense red luminescence, meanwhile dark green, medium green and light tsavorites also yield red, but less intense and darker luminescence [Fig. 17]. An orange luminescence was observed in the case of orange hessonite. The behaviour of grossular under the influence of cathode beam differs from that of other investigated garnets - it has a characteristic dark brownish-green luminescence. It is generally known that the red luminescence is incident to the presence of $\mathrm{Fe}$ (III), whereas the green luminescence is incident to the presence of $\mathrm{Mn}$ (II) [21].

When comparing the results obtained with the data on the chemical composition of garnets (Table 4) it can be concluded that the intense red luminescence in the case of pyrope and rhodolite correlates well with the high content of $\mathrm{Fe}(\mathrm{III})$ - they have. ca. $20 \%$ of $\mathrm{Fe}_{2} \mathrm{O}_{3}$, as well as with the presence of small amounts of $\mathrm{Mn}(\mathrm{II})$, which can intensify the luminiscence. The less intense red luminescence of all investigated tsavorites can be attributed to the absence of $\mathrm{Fe}$ (III), but to the presence of $\mathrm{V}(\mathrm{V})$ and $\mathrm{Mn}(\mathrm{II})$ in the samples (Table 4). The orange luminescence of orange hessonite can be also connected with the presence of Fe(III) (ca. 10 times less than in the case of pyrope and rhodolite) and Mn(II). The cause of brownish-green luminescence of grossular can be in the simultaneous presence of relatively small amounts of $\mathrm{Fe}(\mathrm{III}), \mathrm{Cr}(\mathrm{III})$ and $\mathrm{V}(\mathrm{V})$ and, especially, $\mathrm{Mn}$ (II) (Table 4).

In addition, the cathodoluminescence images of tsavorites show the seasonality of the garnet growing zone, which is prime in medium green tsavorite (Fig. 17).

\section{Visible spectra of garnets}

Generally it is agreed that certain elements cause the colours in certain garnets; likewise, the light absorption lines and bands in garnets are attributable to specific elements. It will be recalled that chromium is responsible for the colours of a number of red and green stones, e.g. the rare 


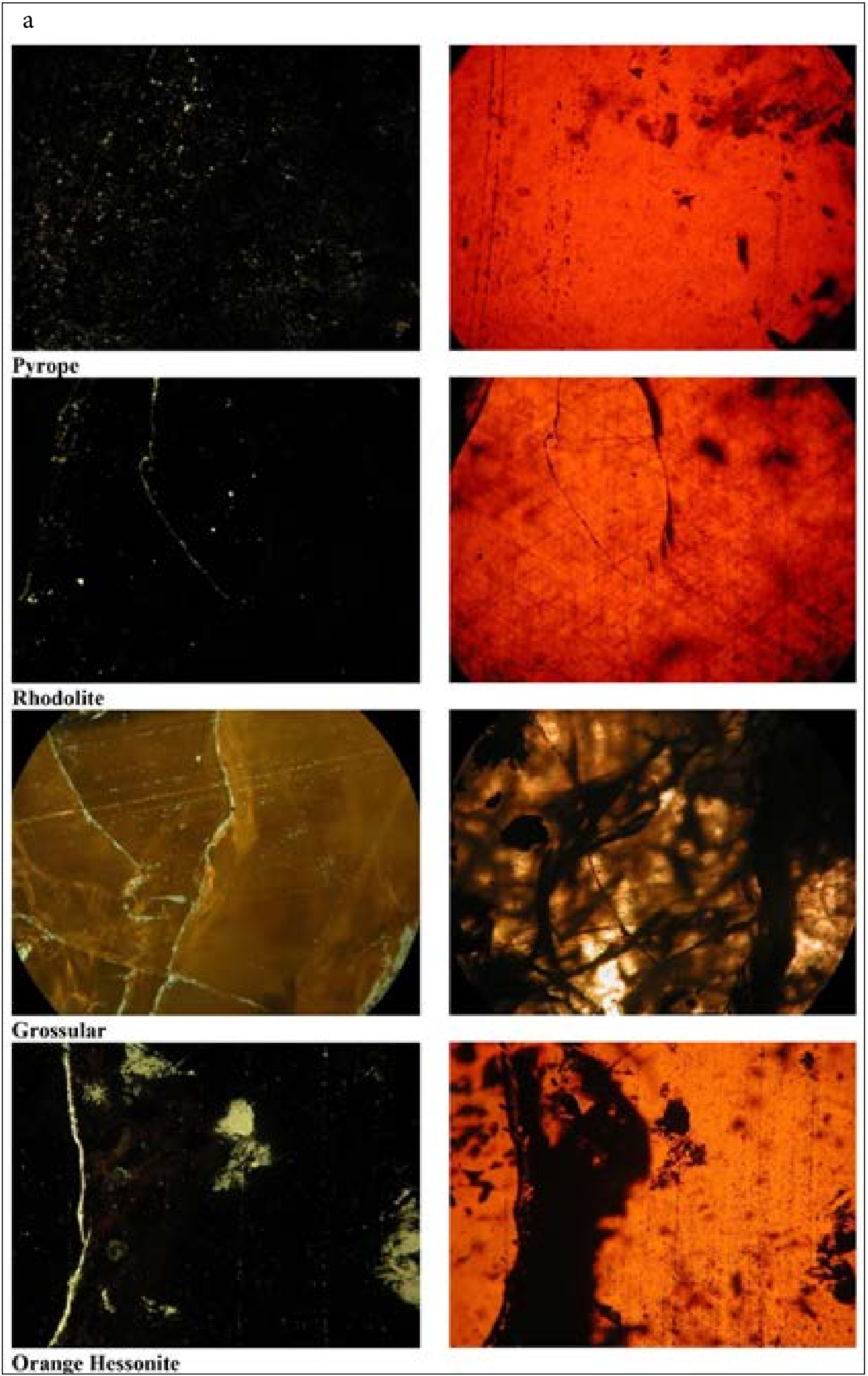

Fig. 17. Polarized light (a) and cathodoluminiscence (b) micrograph pairs of silicate garnets 

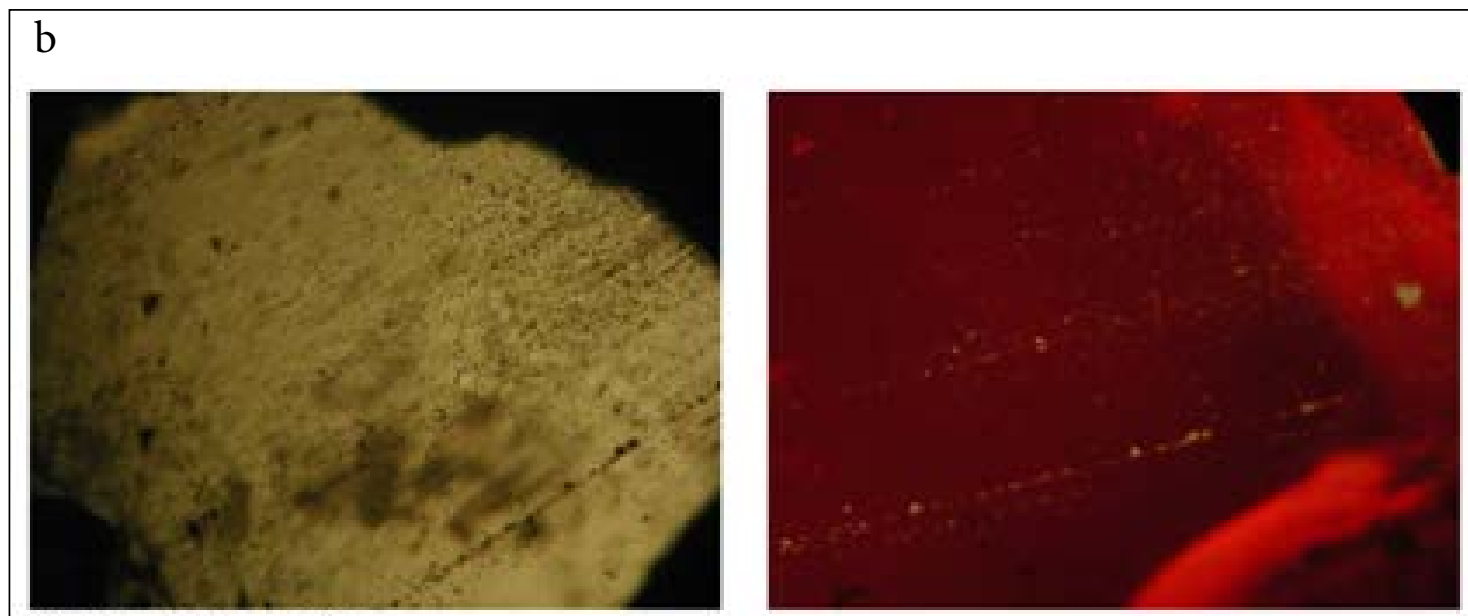

\section{Dark green tsavorite}
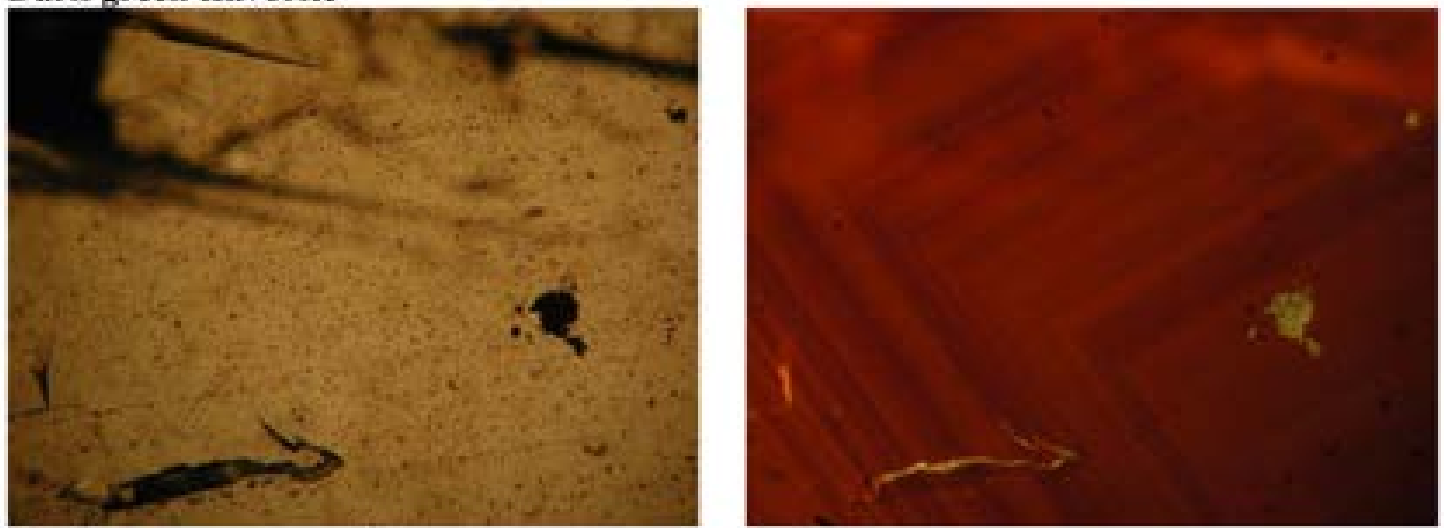

\section{Medium green tsavorite}
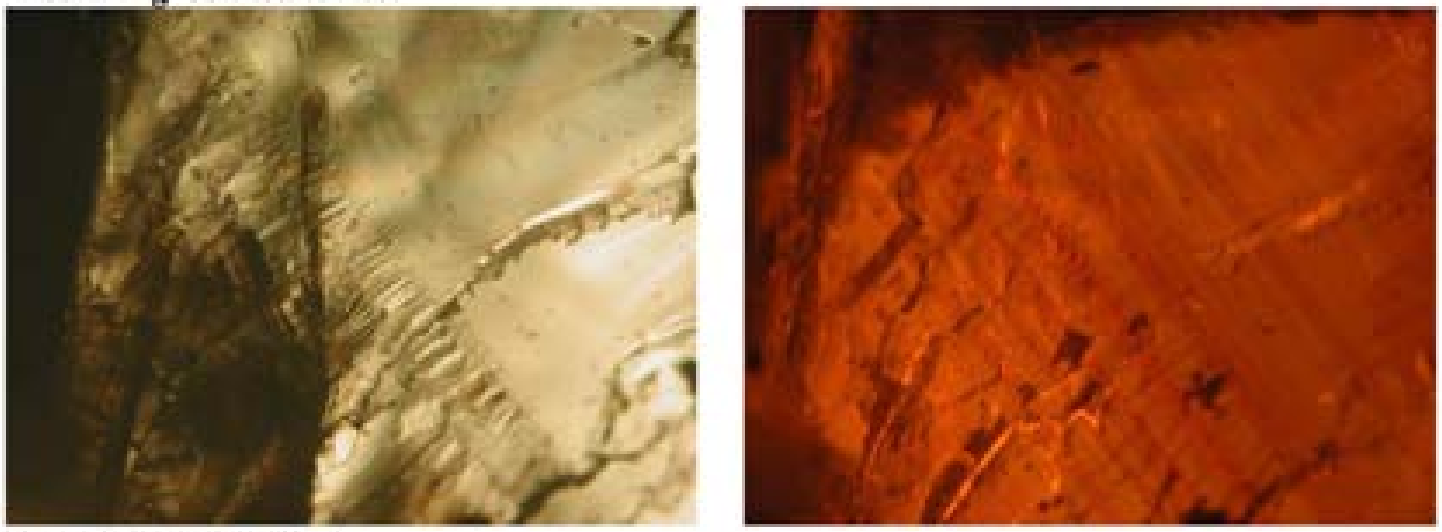

Light green tsavorite

Fig. 17. (Continued) Polarized light (a) and cathodoluminiscence (b) micrograph pairs of silicate garnets

chrome-pyrope garnet. In combination with iron it is partly responsible for the colours of demantoid garnet. The absorption lines caused by chromium are mainly fine ones in the red, together with a broad band in the center of the spectrum in the yellow and green. The position, width and intensity of this band largely determines the precise hue of the stone. Iron is another important colour-causing agent in gemstones. There are two categories of iron spectra: that caused by ferric iron (Fe(III)) and that caused by ferrous iron (FeII), e.g. demantoid garnet. In general, the fines and bands caused by iron are found in the blue and green part of the spectrum. Manganese is responsible for the colour in rhodolite and spessartite garnet. Lines attributed to it in the spectra of these stones are centered in the blue, violet and even in the ultraviolet [23-27].

The visible spectra of light absorption of natural silicate garnets were also investigated and discussed in Refs [28-36. 


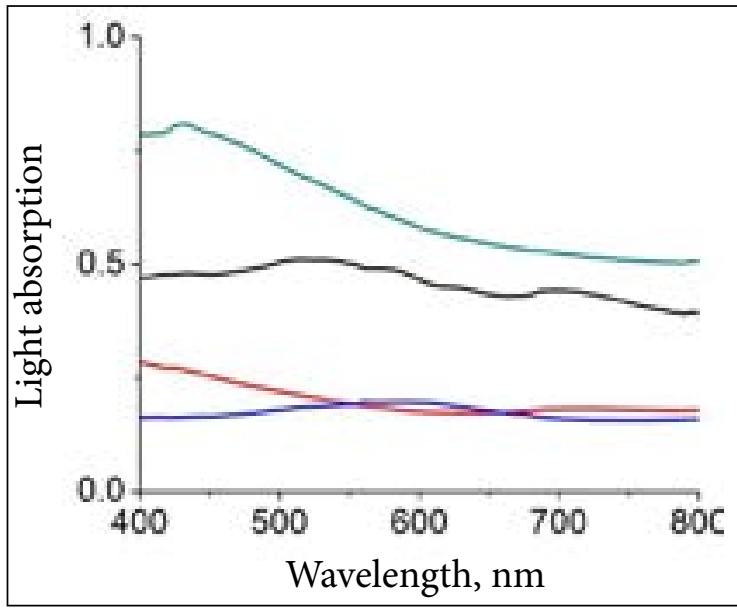

Fig. 18. Light absorption spectra of pyralspites. A black line is pyrope, a red line shows almandine, a blue line is rhodolite and a green line is spessartine

The light absorption spectra of investigated pyralspites differs - the highest intensity is observed for spessartine and pyrope, whereas almandine and rhodolite exhibit lower intensity (Fig. 18). In the visible region, spessartine has the well expressed maximum at $430 \mathrm{~nm}$. Later, the absorbance values decrease continuously going to the side of longer waves. The absorption features of this garnet are due mostly to $\mathrm{Mn}$ (II) and Fe(III) (Table 4) - the absorbance peak at $430 \mathrm{~nm}$ is related to $\mathrm{Fe}$ (III) [3] and the absorbance in the region from 410 to $525 \mathrm{~nm}$ to $\mathrm{Mn}$ (II) [3, 28, 35]. The spectrum of pyrope is more complicate (Fig. 18). A comparatively broad maximum is seen in the region from 490 to $560 \mathrm{~nm}$, the highest value being at $530 \mathrm{~nm}$. This is a peak related to the presence of both $\mathrm{Mn}$ (II) and Fe(III) [27, 31] (Table 4). The less expressed peak is observed at $695-700 \mathrm{~nm}$. Usually in this region of the spectrum $\mathrm{Cr}$ (III) absorbs the light [23-27], and the garnet contains some amount of not detectable impurities of this element. The spectrum of almandine shows the decrease in light absorbance going from $400 \mathrm{~nm}$ to the side of longer waves up to $635 \mathrm{~nm}$, whereas from $640 \mathrm{~nm}$ a weak increase begins. A small peak was found at $720 \mathrm{~nm}$. In contrast to almandine, the increase in intensity of the spectrum of rhodolite is observed going to the side of longer waves beginning from 400 up to $560 \mathrm{~nm}$, where the highest value of light absorbance was observed (Fig. 18). Later, going to the side of longer waves, the values of light absorbance slightly decrease. The spectra of almandine and rhodolite also have colour-causing elements - Fe (III) and

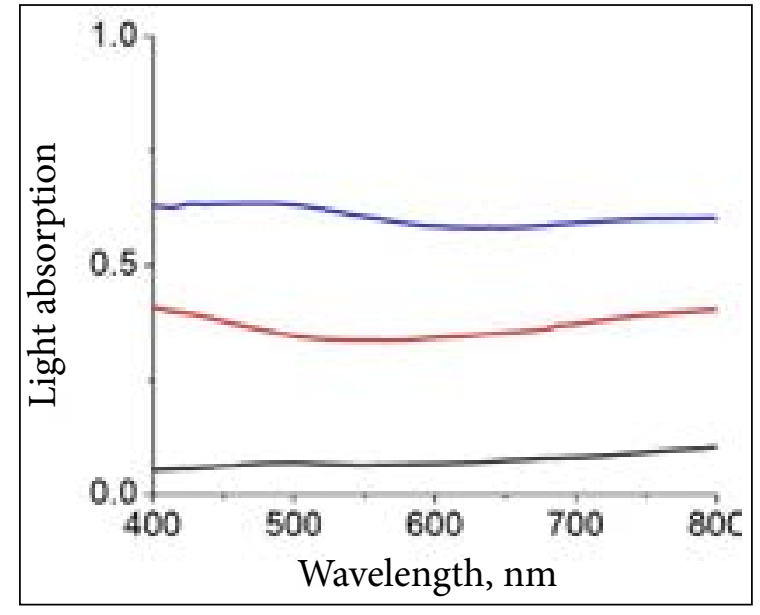

Fig. 19. Light absorption spectra of ugrandites. A black line is uvarovite, a red line shows grossular and a blue line is andradite

Mn(II) (Table 4). The higher content of Fe(III) is responsible for the higher light absorbance values of almandine, compared with that of rhodolite at wavelength of 400-500 nm.

When investigating the spectrophotometric properties of ugrandites, it was found that andradite has the highest intensity in light absorbance (Fig. 19). Its spectrum has a broad maximum in the region from 430 to $500 \mathrm{~nm}$, the maximum being at $470 \mathrm{~nm}$. Beginning from $470 \mathrm{~nm}$ to the side of longer waves the light absorbance slightly decreases up to $750 \mathrm{~nm}$, whereas later slightly increases (Fig. 19). The garnet colour is mainly due to Fe(III) [33, 34] (Table 4). The light absorption of grossular in the visible region decreases continuously from 400 to $565 \mathrm{~nm}$ with further increase up to $800 \mathrm{~nm}$, no specific peaks were observed (Fig. 19). The first region of the spectra (decrease in absorbance) can be connected with the presence of iron(III) and manganese(II) in the sample [32], whereas the second one with the presence of the same iron(III) together with $\mathrm{Cr}$ (III) [24] or iron(III) and manganese [23] (see Table 4). The values of the light absorbance of uvarovite are lowest from the investigated ugrandites (Fig. 19). The broad maximum can be recognized in the region from 460 to $540 \mathrm{~nm}$, the highest value being at $500 \mathrm{~nm}$.

The spectra of two other varieties of grossular - pink hessonite and orange hessonite - differ from that of grossular (Fig. 20). They are much more complicated and have many absorption peaks. The red hessonite exhibits peaks at 425 $430,505,570$ and $690 \mathrm{~nm}$, whereas the orange 


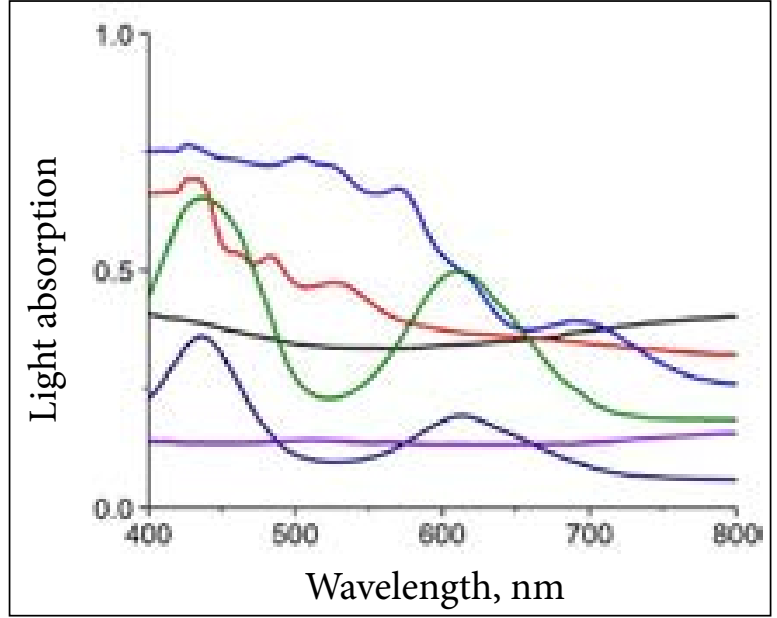

Fig. 20. Light absorption spectra of grossular and its varieties. A black line is grossular, a red line is orange hessonite, a blue line shows pink hessonite, an olive line is dark green tsavorite, a navy line is medium green tsavorite and a violet line shows light green tsavorite

hessonite displays peaks at 430, 485 and $525 \mathrm{~nm}$. According to the data of our chemical analysis, $\mathrm{Fe}(\mathrm{III})$ and $\mathrm{Mn}$ (II) are responsible for the light absorbance in both hessonites. The data of literature confirm our conclusion [24.

The light absorption spectra of the dark green and medium green tsavorites display two broad bands centered at about 435 and $610 \mathrm{~nm}$, both bands are well defined. The $435 \mathrm{~nm}$ band is more intense than that at $610 \mathrm{~nm}$, which is slightly broader (Fig. 20). These peaks become more intensive with increasing of the V(III) and Mn(II)content [23-26] (see Table 4). The spectrum of light green tsavorite differs from other tsavorites (Fig. 20) - the general intensity is much lower. The broad band from 450 to $550 \mathrm{~nm}$ (centered at $510 \mathrm{~nm}$ ) is observed. The possible origin could be not detectable impurities of Fe(III).

The spectra of andradite and its varieties, rainbow garnet, demantoid and topazolite, are seen in Fig. 21. The intensity of the spectrum of the rainbow garnet is lower than that of andradite (Fig. 21). Two maximum values are observed in the spectrum at 425 and $580 \mathrm{~nm}$. The values of the light absorption of investigated demantoid and topazolite are low, therefore it is difficult to identify specific peaks (Fig. 21). The highest intensity of light absorption for demantoid was determined at $400 \mathrm{~nm}$, and a nonintense peak was found at $660 \mathrm{~nm}$. In the case of topazolite, a nonintense peak was observed at $500 \mathrm{~nm}$. The main

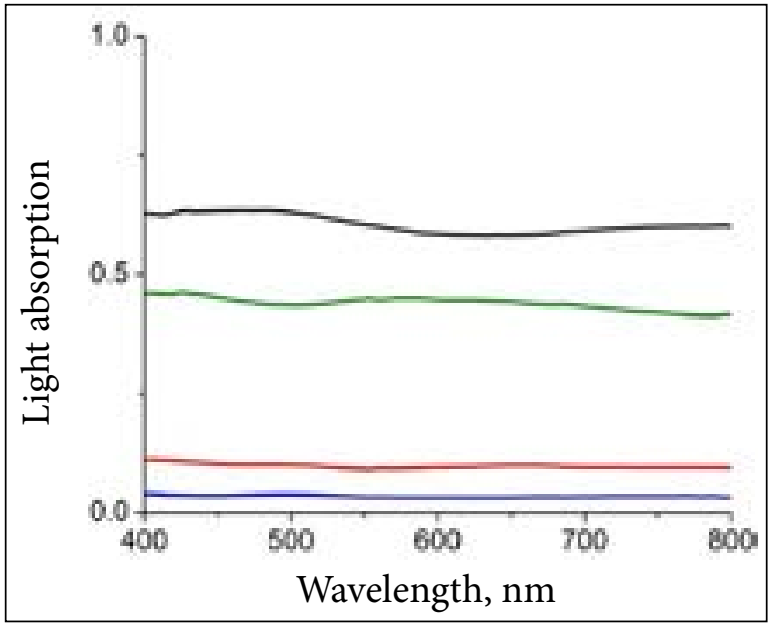

Fig. 21. Light absorption spectra of andradite and its varieties. A black line is andradite, a red line shows demantoid, a blue line is topazolite and an olive line shows rainbow garnet

colour-causing agent is $\mathrm{Fe}(\mathrm{III})$, probably together with Mn(II) (see Table 4).

\section{Raman spectroscopy}

Raman spectroscopy provides insights into the molecular structure and short-range ordering of garnets [37-46]. The Raman spectra of different garnets are displayed in Figs 22-25. The vibrational bands of the studied compounds can be divided into several groups: (i) internal vibrations of $\mathrm{SiO}_{4}$ tetrahedra (symmetric stretching, $v_{1}$; asymmetric stretching, $v_{3}$; symmetric bending, $v_{2}$; asymmetric bending, $v_{4}$ ), (ii) translation of $\mathrm{SiO}_{4}$ tetrahedra, $\mathrm{T}\left(\mathrm{SiO}_{4}\right)$, (iii) rotation of $\mathrm{SiO}_{4}$ tetrahedra, $\mathrm{R}\left(\mathrm{SiO}_{4}\right)$ and (iv) translation of $\mathrm{YO}_{6}$ octahedra $\left(\mathrm{Y}=\mathrm{Fe}^{3+}, \mathrm{Cr}^{3+}\right.$ and $\left.\mathrm{Al}^{3+}\right), \mathrm{T}(\mathrm{M})$ 42-45. The symmetric stretching vibrational mode of $\mathrm{SiO}_{4}$ group $\left(v_{1}\right)$ appears as a medium-intense band in the frequency region $874-918 \mathrm{~cm}^{-1}$. The asymmetric stretching mode $v_{3}$ appears as a lower intensity band (several features) at slightly higher frequencies. The deformation vibrational modes of $\mathrm{SiO}_{4}$ tetrahedra $v_{2}$ and $v_{4}$ are visible in the spectral region $420-640 \mathrm{~cm}^{-1}$. It should be noted that the asymmetric bending mode $v_{4}$ usually displays higher frequency bands [42]. The mode associated with the rotation of $\mathrm{SiO}_{4}$ tetrahedra $\mathrm{R}\left(\mathrm{SiO}_{4}\right)$ appears in the lower frequency region $350-420 \mathrm{~cm}^{-1}$ [42]. Finally, the translation modes $\mathrm{T}\left(\mathrm{SiO}_{4}\right)$ and $\mathrm{T}(\mathrm{M})$ usually can be observed at wavenumbers lower than $340 \mathrm{~cm}^{-1}$ [42, 43, 45,.

The Raman spectra of pyrope and almandine are very similar (Figs 22a, b). The most intense 


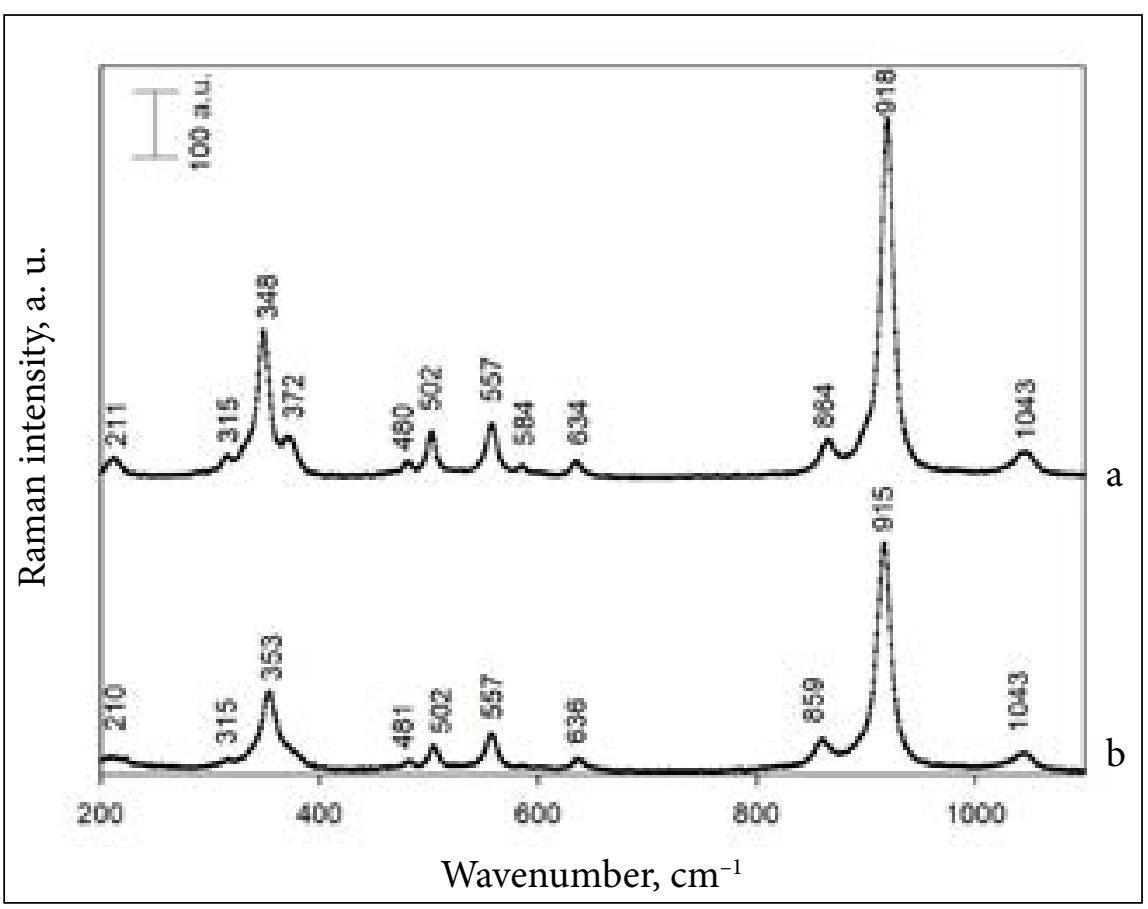

Fig. 22. Raman spectra of pyrope (a) and of alamandine (b)

band located at $915-918 \mathrm{~cm}^{-1}$ belongs to the $v_{1}$ mode of the stretching vibration of $\mathrm{SiO}_{4}$ group. The second strong band peaked at $348-353 \mathrm{~cm}^{-1}$ is associated with the $\mathrm{R}\left(\mathrm{SiO}_{4}\right)$ vibrational mode [44]. The considered compounds slightly differ in their composition; the relative amount of $\mathrm{Fe} /$ $\mathrm{Mg}$ ions increases going from pyrole to almandine
(Table 4). Because Raman bands are well-defined the following correlation can be recognized based on the analysis of shifts of two major Raman bands; the increase in the relative amount of $\mathrm{Fe} / \mathrm{Mg}$ ions results in the decrease of $v_{1}$ mode frequency and the increase in $\mathrm{R}\left(\mathrm{SiO}_{4}\right)$ mode frequency (Figs 22a, b). This is related with slight changes in the lattice

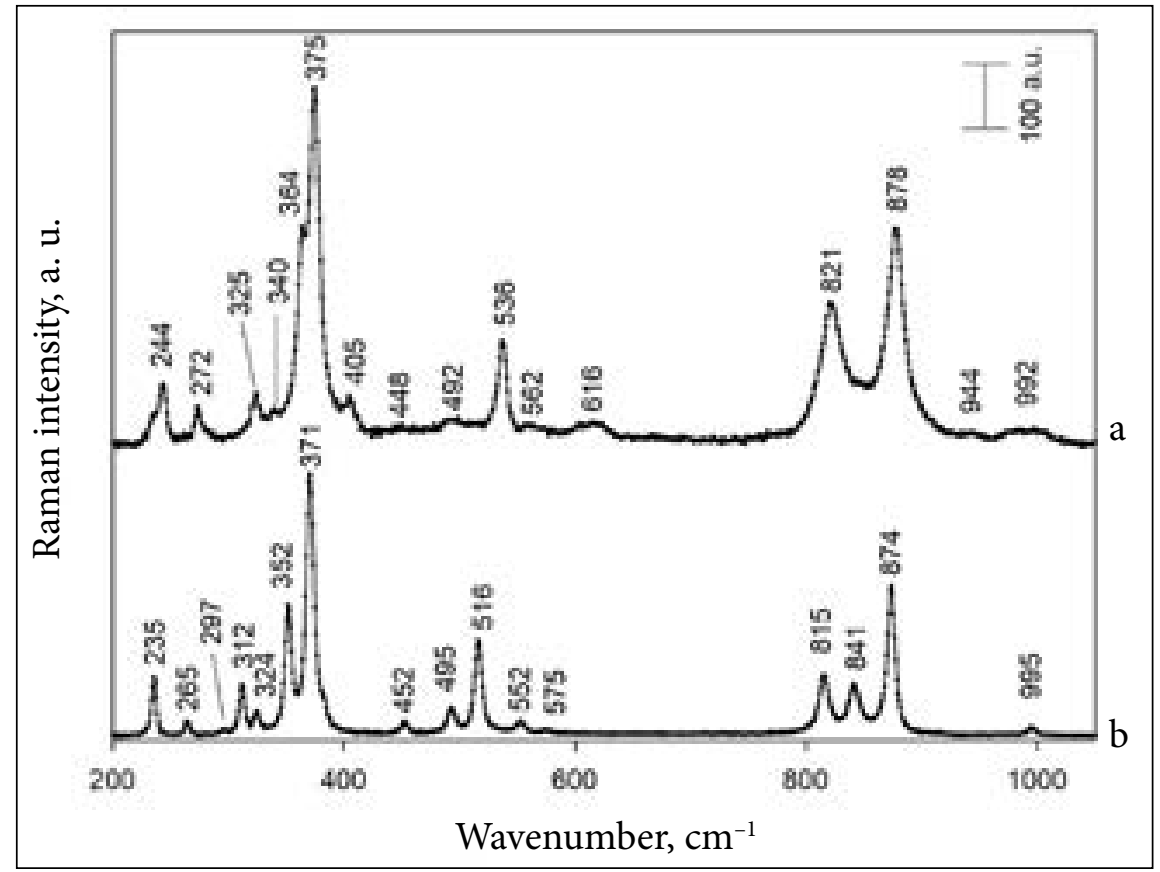

Fig. 23. Raman spectra of andradite (a) and of demantoid (b) 
constant and the local structure of compounds. Similar spectra changes were observed in the series of pyrope-garnet compounds [44]. The replacement of $\mathrm{Mg}^{2+}$ ions by $\mathrm{Ca}^{2+}$ ions resulted in the decrease in $v_{1}$ and the increase in $\mathrm{R}\left(\mathrm{SiO}_{4}\right)$ mode frequencies.

Figures $23 \mathrm{a}$ and $\mathrm{b}$ compare the Raman spectra of andradite and demantoid. The samples differ in the ratio of $\mathrm{Fe} / \mathrm{Al}$ ions (Table 4). One can see that the increase in the $\mathrm{Fe} / \mathrm{Al}$ ratio results in a clear decrease in the $v_{4}$ mode associated with the asymmetric deformation vibration of the $\mathrm{SiO}_{4}$ group frequency from 536 to $516 \mathrm{~cm}^{-1}$. In addition, the andradite Raman bands $v_{1}\left(878 \mathrm{~cm}^{-1}\right), \mathrm{R}\left(\mathrm{SiO}_{4}\right)$ (375 and $364 \mathrm{~cm}^{-1}$ ) and $v_{4}$ are broader compared with similar demantoid bands. This observation indicates that a lower $\mathrm{Fe} / \mathrm{Al}$ ratio results in a slight disordering of the crystalline structure.

Figures 24a, b and c compare the Raman spectra of grossular, cinnamon hessonite and orange hessonite, respectively. One can see that cinnamon hessonite exhibits narrow bands in a broad spectral region, indicating a high crystalline structure of the studied compound. In contrast, grossular exhibits broadened bands, especially considering the $\mathrm{R}\left(\mathrm{SiO}_{4}\right)$ and $v_{4}$ modes located at 350 and $524 \mathrm{~cm}^{-1}$, respectively. In addition, this compound shows a considerably suppressed $v_{1}$ band intensity. This might be related to the presence of a small amount of different cations $\left(\mathrm{Mg}^{2+}, \mathrm{Cr}^{3+}\right.$ and $\left.\mathrm{Mn}^{2+}\right)$ (Table 4) which may induce the structural disordering and presence of defects in the lattice. The appearance of broad features at 595 and $378 \mathrm{~cm}^{-1}$ along with the relatively narrow bands at 908 and $354 \mathrm{~cm}^{-1}$ in the case of orange hessonite points to the presence of both amorphous-like and crystalline phases.

Figures 25a, b and c compare the Raman spectra of dark green tsavorite, medium green tsavorite and light green tsavorite, respectively. The peak positions of main bands are very similar, while the relative intensities of the bands differ considerably. The peak positions of $v_{1}, \mathrm{R}\left(\mathrm{SiO}_{4}\right)$ and $v_{4}$ modes are visible in the narrow frequency regions 881-883, 349-350/375 (two bands) and 525/549 (two bands) $\mathrm{cm}^{-1}$, respectively. A considerable decrease in the relative intensity of the $v_{1}$ band for medium green tsavorite might be related to the presence of $\mathrm{Cr}^{3+}$ ions (Table 4) [46]. In addition, the widths of the $v_{1}$ and $\mathrm{R}\left(\mathrm{SiO}_{4}\right)$ bands were found to be highest for this sample indicating a crystalline structure disordering for this sample. The broad low intensity bands visible at 603-605 and $437-439 \mathrm{~cm}^{-1}$ in all three samples might be related to the presence of $\mathrm{TiO}_{2}$ rutile phase [47]. Finally, the broad band near $525 \mathrm{~cm}^{-1}$ may have contribution from the $\mathrm{V}_{2} \mathrm{O}_{3}$ phase [48].

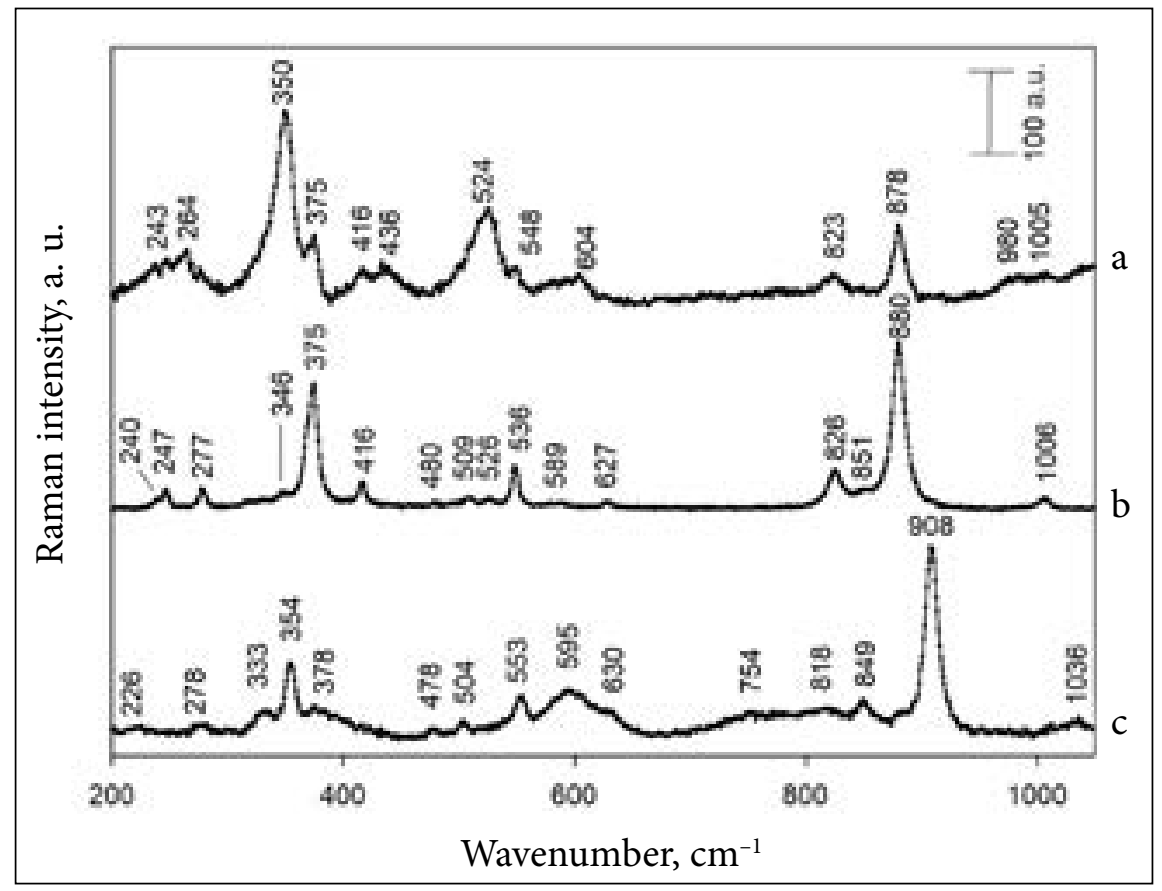

Fig. 24. Raman spectra of grossular (a), cinnamon hessonite (b) and orange hessonite (c) 


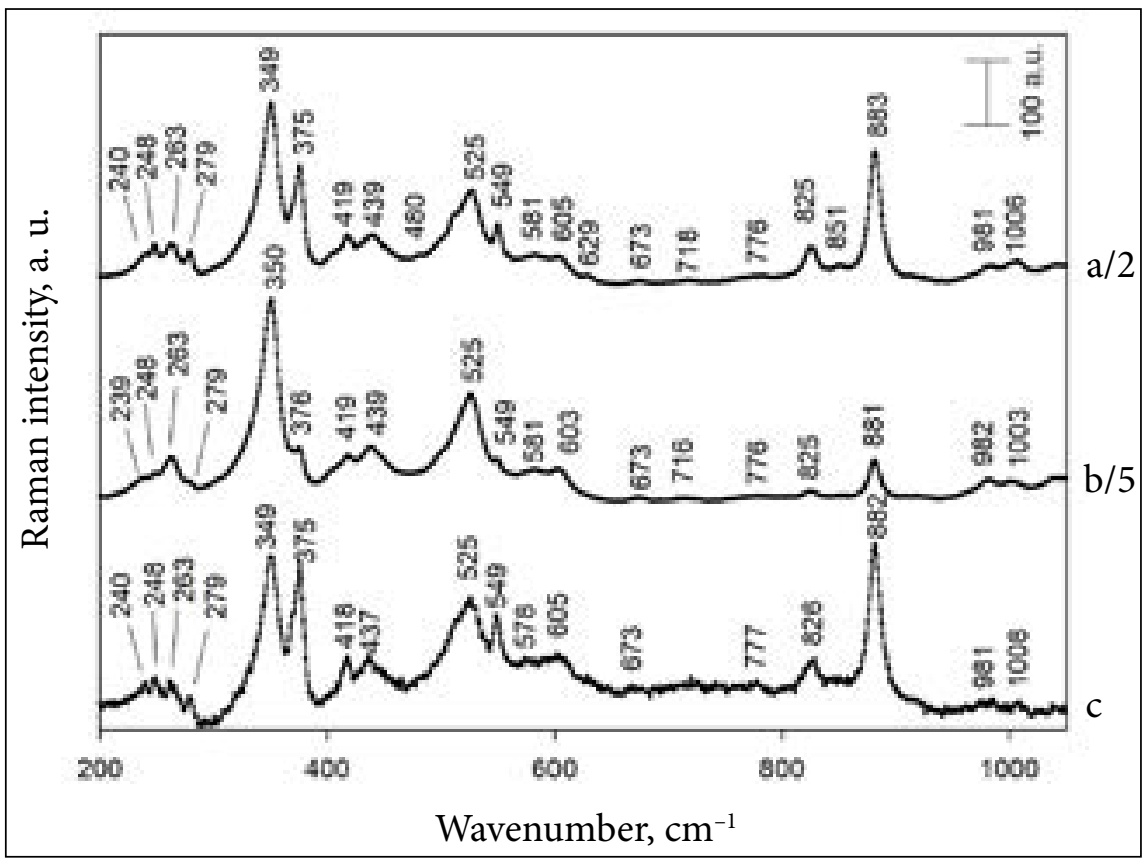

Fig. 25. Raman spectra of light green tsavorite (a), medium green tsavorite (b) and dark green tsavorite (c)

\section{CONCLUSIONS}

Two kinds of natural silicate garnets from the known origin countries were investigated: pyralspites - pyrope (Russia), almandine (India), rhodolite (India), spessartine (India), blue colourchange garnet (Sri Lanka) and ugrandites - andradite (Russia), demantoid (Russia), topazolite (Russia), rainbow garnet (Japan), grossular (KenyaTanzania), colourless grossular (India), light orange grossular (India), dark green tsavorite (Tanzania), medium green tsavorite (Kenya), light green tsavorite (Kenya), orange hessonite (Sri Lanka), pink hessonite (Sri Lanka), cinnamon hessonite (India) and uvarovite (Russia). According to the results of chemical analysis, all garnets have silicon (IV), $\mathrm{Ca}(\mathrm{II})$ and $\mathrm{Al}(\mathrm{III})$ in their composition. The quantity of $\mathrm{SiO}_{2}$ varies between 22.80 and $55.44 \%, \mathrm{CaO}$ between 0.48 and $35.14 \%$ and $\mathrm{Al}_{2} \mathrm{O}_{3}$ between 1.18 and $44.07 \%$. All garnets except demantoid, rainbow garnet orange, pink and cinnamon hessonites contain $\mathrm{Mg}(\mathrm{II})$. The quantity of $\mathrm{MgO}$ in those garnets varies between 0.50 and $16.16 \%$. Iron(III) is present in practically all garnets, except all tsavorites. The amount of $\mathrm{Fe}$ (III) varies between 0.25 and $35.18 \%$. The other than Fe(III) colour-causing elements, e.g. $\mathrm{Mn}(\mathrm{II}), \mathrm{Cr}(\mathrm{III})$ or V(III), are present in practically all investigated garnets, except andradite, demantoid and cinnamon hessonite.
After the measurements of the values of the specific gravity of demantoid, grossular, hydrogrossular, green grossular, light orange grossular, dark, medium and light green tsavorites, orange and pink hessonites and uvarovite it was found that the highest value of the specific gravity was measured for uvarovite $\left(3.77 \mathrm{~g} / \mathrm{cm}^{3}\right)$, whereas the lowest value was obtained for hydrogrossular $-3.52 \mathrm{~g} / \mathrm{cm}^{3}$.

After the measurements of the refractive indexes of garnets, having the refractive indexes lower than 1.81 (rhodolite, grossular, dark medium and light tsavorites and orange and pink hessonites), it was determined that rhodolite has the highest value of the refractive index, whereas the lowest value was determined for grossular.

The spectrophotometric measurements of pyralspites and ugrandites confirm that the main colour-causing elements - $\mathrm{Fe}(\mathrm{III}), \mathrm{Mn}$ (II), $\mathrm{Cr}$ (III) and $\mathrm{V}(\mathrm{III})$ - determine the spectral properties of the silicate garnets investigated.

Received 2 September 2021 Accepted 20 September 2021

\section{References}

1. I. Balčiūnaité, A. Kleišmantas, E. Norkus, Chemija, 26, 18 (2015).

2. V. Ruokis, Kristalografija ir optine uolienu mineralogija, 283, Mintis, Vilnius (1966). In Lithuanian. 
3. K. Schmetzer, T. Hainschwang, L. Kiefert, H.-J. Bernhardt, Gems Gemol., 37, 296 (2001).

4. My First Colour Changing Alexandrite-like Garnets [https://www.moregems.com/blogs/news/myfirst-color-changing-alexandrite-like-garnets http://www.secretsofthegemtrade.com/articles 8.htm].

5. K. Schmetzer, H.-J. Bernhardt, Gems Gemol., 35, 196 (1999).

6. Andradite [https://www.mindat.org/min-223. html].

7. J. Stephenson, N. Kuznetsov, InColor, 11, 16 (2009).

8. Topazolite [https://www.mindat.org/min-7535. html].

9. W. Schumann, Gemstones of the World, NAG Press, London (1994).

10. V. V. Bukanov, Russian Gemstones Encyclopedia, 472, Granit, Praha (2006).

11. Gemstone Density: The Definitive Guide [https:// www.ajsgem.com/articles/gemstone-density-definitive-guide.html].

12. N. N. Kornilov, Yu. P. Solodova, Jewel Gemstones, 239, Nedra, Moscow (1983). In Russian.

13. R. Newman, Gemstone Buying Guide, 2nd edn., 156, International Jewelry Publications, Los Angeles (2005).

14. Mineral Densities [https://www.engineeringtoolbox.com/mineral-density-d_1555.html].

15. Gemstone Refractive Index: The Definitive Guide [https://www.ajsgem.com/articles/gemstone-refractive-index-definitive-guide.html].

16. K. M. Stockton, D. V. Manson, Gems Gemol., 21, 205 (1985).

17. D. J. Marshall, Cathodoluminescence of Geological Materials, 146, Unwin Hyman, Boston (1988).

18. M. Pagel, V. Barbin, P. Blanc, D. Ohnenstatter, Cathodoluminescence in Geosciences, 501, SpringerVerlag, Berlin (2000).

19. S. Boggs, D. Krinsley, Application of Cathodoluminescence Imaging to the Study of Sedimentary Rocks, 165, University Press, New York, Cambridge (2006).

20. A. Gucsik (ed.), Cathodoluminiscence and Its Application in the Planetary Sciences, 160, SpringerVerlag, Berlin, Heidelberg (2009).

21. J. Götze, Microsc. Microanal., 18, 1270, (2012).

22. P. Gadas, M. Novak, D. Talla, M. Vasinova Galiova, Miner. Petrol, 107, 311 (2013).

23. P. G. Manning, Canad. Mineral., 9, 237 (1967).
24. G. A. Slack, R. M. Chrenko, J. Opt. Soc. Amer., 61, 1325 (1971).

25. C. M. Stockton, D. V. Manson, Gems Gemol., 21, 205 (1985).

26. J. Feneyrol, G. Giuliani, D. Ohnenstetter, et al., Eur. J. Mineral., 26, (2014).

27. Z. Sun, A. C. Palke, N. Renfro, Gems Gemol., 51, 348 (2015).

28. B. M. Laurs, K. Knox, Gems Gemol., 37, 278 (2001).

29. C. H. Liu, C. Y. Chen, T. Shao, Z. B. Li, A. H. Shen, Spectrosc. Spectr. Anal., 44, 2148 (2020).

30. K. Schmetzer, H.-J. Bernhardt, G. Bosshart, T. Hainschwang, J. Gemol., 31, 235 (2009).

31. T. Chen, Y. G. Liu, Z. W. Yin, N. Liu, Spectrosc. Spectr. Anal., 33, 2964 (2013).

32. J.M. Yauri, N. F. Cano, S. Watanabe, Radiat. Measur., 43, 1331 (2008).

33. C. Lin, Bull. Mineralogy, 104, 218 (1981).

34. I. Adamo, G. D. Gatta, N. Rotiroti, V. Diella, A. Pavese, Eur. J. Mineral., 23, 91 (2011).

35. Y. Qiu, Y. Guo, Minerals, 11, 865 (2021).

36. E. Gubelin, K. Schmetzer, Gems Gemol., 18, 197 (1982).

37. A. M. Hofmeister, A. Chopelas, Phys. Chem. Minerals, 17, 503 (1991).

38. B. A. Kolesov, C. A. Geiger, Phys. Chem. Minerals, 25, 142 (1998).

39. D. Bersani, P. P. Lottici, Anal. Bioanal. Chem., 397, 2631 (2010).

40. D. Bersani, S. Andó, P. Vignola, et al., Spectrochim. Acta, Part A, 73, 484 (2009).

41. V. Diella, R. Bocchio, N. Marinoni, et al., Minerals, 9, 728 (2019).

42. P. Makreski, T. Runčevski, G. Jovanovski, J. Raman Spectrosc., 42, 72 (2011).

43. P. Mingsheng, H. K. Mao, L. Dien, E. C. T. Chao, Chinese J. Geochem., 13, 176 (1994).

44. W. Du, B. Han, S. M. Clark, Y. Wang, X. Liu, Phys. Chem. Minerals, 45, 197 (2018).

45. J. Štubňa, P. Bačik, J. Fridrichova, et al., Minerals, 9, 164 (2019).

46. J. Zuo, C. Xu, B. Hou, C. Wang, Y. Xie, Y. Qian, Raman Spectrosc., 27, 921 (1996).

47. O. Frank, M. Zukalova, B. Laskova, J. Kürti, J. Koltai, L. Kavan, Phys. Chem. Chem. Phys., 14, 14567 (2012).

48. X.-B. Chen, M.-H. Kong, J.-Y. Choi, H.-T. Kim, Phys D. Appl. Phys., 49, 465304 (2016). 
Irena Balčiūnaitė, Ilja Ignatjev, Donatas Kaminskas,

Gediminas Niaura, Eugenijus Norkus

GAMTINIỤ SILIKATINIŲ GRANATŲ

APIBŪDINIMAS NEARDANČIAIS TYRIMŲ

METODAIS

Santrauka

Buvo tirtos dvi grupès gamtinių silikatinių granatų iš žinomų kilmès vietovių: piralspitai - piropas (Rusija), alamandinas (Indija), rodolitas (Indija), špesartinas (Indija), mèlynas spalvas keičiantis granatas (Šri Lanka) bei ugranditai - andraditas (Rusija), demantoidas (Rusija), topazolitas (Rusija), vaivorykštinis granatas (Japonija), grosuliaras (Kenija-Tanzanija), bespalvis grosuliaras (Indija), šviesiai oranžinis grosuliaras (Indija), tamsiai žalias tsavoritas (Tanzanija), vidutinio žalsvumo tsavoritas (Kenija), šviesiai žalias tsavoritas (Kenija), oranžinis hesonitas (Šri Lanka), rausvas hesonitas (Šri Lanka), cinamoninis hesonitas (Indija) ir uvarovitas (Rusija). Granatų chemine sudetis buvo nustatyta skenuojančiu elektroniniu mikroskopu. Daliai tirtų granatų buvo nustatytos specifinio svorio bei šviesos lūžio rodiklio vertès. Minèti gamtiniai silikatiniai granatai buvo apibūdinti spektroskopiniais metodais: matomos šviesos spektrofotometrija, Ramano spektroskopija bei katodoliuminescensine mikroskopija. 